\title{
Oxytocin Promotes Long-Term Potentiation by Enhancing Epidermal Growth Factor Receptor-Mediated Local Translation of Protein Kinase $\mathrm{M} \zeta$
}

\author{
Yu-Ting Lin, ${ }^{1,2}$ Chiung-Chun Huang, ${ }^{1}$ and Kuei-Sen $\mathrm{Hsu}^{1,2}$ \\ 'Department of Pharmacology, and 2Institute of Basic Medical Sciences, College of Medicine, National Cheng Kung University, Tainan 701, Taiwan
}

In addition to triggering the birthing process and milk release, the hypothalamic neuropeptide oxytocin (OXT) plays an important role in the regulation of complex social cognition and behavior. Previous work has shown that OXT can regulate hippocampal synaptic plasticity and improve hippocampus-dependent cognitive functions in the female mice, but the underlying mechanisms remain largely unclear. Here, we demonstrate that OXT promotes the maintenance of long-term potentiation (LTP) induced by one train of tetanic stimulation (TS) in the CA1 region of hippocampal slices from both nulliparous female and male rats through a previously unknown mechanism involving OXT receptor (OXTR)-dependent and epidermal growth factor receptor (EGFR)-mediated local translation of an atypical protein kinase C isoform, protein kinase $\mathrm{M} \zeta(\mathrm{PKM} \zeta)$, in dendrites. Using pharmacological and biochemical approaches, we show that both the conventional OXTR-associated signaling pathway $\left(\mathrm{G}_{\mathrm{q} / 11}\right.$-coupled phospholipase $\left.\mathrm{C}\right)$ and the transactivated EGFR downstream signaling pathways (phosphatidylinositol $3 \mathrm{ki}$ nase and extracellular signal-regulated kinase 1/2) are involved in the regulation of OXT. In addition, OXT stimulates local dendritic PKM $\zeta$ mRNA translation via activation of a mammalian target of rapamycin-regulated mechanism. Furthermore, blockade of OXTR results in a modest decrease in the ability to maintain late-phase LTP induced by three trains of TS. These results reveal a novel OXTR-to-EGFR communication to regulate the new synthesis of PKM $\zeta$, which functions to promote the maintenance of LTP at hippocampal CA1 synapses.

\section{Introduction}

The neuropeptide oxytocin (OXT) is primarily synthesized by magnocellular neurons in the paraventricular and supraoptic nuclei of the hypothalamus (Gainer and Wray, 1992; Lee et al., 2009). In addition to neurosecretory projections to the posterior pituitary, OXT also travels along the axonal projections from parvocellular neurons of the hypothalamus to discrete brain regions, including the hippocampus, amygdala, striatum, suprachiasmatic nucleus, bed nucleus of stria terminalis (BNST), and brainstem, where it acts as a neuromodulator or neurotransmitter and thereby influences neurotransmission in these regions (Buijs and Swaab, 1979; Sofroniew, 1983; Young and Gainer, 2003; Meyer-Lindenberg et al., 2011). Since the first discovery that central OXT can induce maternal behavior in virgin rats (Pedersen and Prange, 1979), growing evidence has revealed a significant contribution of brain OXT in the regulation of various social behaviors, including social recognition, aggression, and affiliation, as well as nonsocial behaviors, such as learning and memory, anxiety, depression, and stress (Neumann, 2008; Neumann and Landgraf, 2008; Lee et al., 2009; Meyer-Lindenberg et

Received May 21, 2012; revised Sept. 4, 2012; accepted Sept. 7, 2012.

Author contributions: Y.-T.L., C.-C.H., and K.-S.H. designed research; Y.-T.L. and C.-C.H. performed research; Y.-T.L., C.-C.H., and K.-S.H. analyzed data; Y.-T.L., C.-C.H., and K.-S.H. wrote the paper.

This work was supported by research grants from the National Health Research Institute (NHRI-EX100-9618NI) and from the National Science Council (NSC101-2321-B-006-024), Taiwan.

Correspondence should be addressed to Dr. Kuei-Sen Hsu, Department of Pharmacology, College of Medicine, National Cheng Kung University, No. 1, University Road, Tainan 701, Taiwan. E-mail: richard@mail.ncku.edu.tw.

DOI:10.1523/JNEUROSCI.2429-12.2012

Copyright $\odot 2012$ the authors $\quad 0270-6474 / 12 / 3215476-13 \$ 15.00 / 0$ al., 2011). Furthermore, the biological actions of OXT are primarily mediated by the activation of OXT receptors (OXTR), which belong to the class I family of G-protein-coupled receptors (GPCR) and are coupled to phospholipase C (PLC) through $\mathrm{G}_{\alpha \mathrm{q} / 11}$ (Gimpl and Fahrenholz, 2001). OXTR is widely expressed throughout the brain and is especially prominent in the hippocampus, amygdala, olfactory bulb, BNST, nucleus accumbens, and ventromedial hypothalamic nucleus (Insel et al., 1991; Veinante and Freund-Mercier, 1997).

The hippocampus is one of the most susceptible brain areas to the effects of OXT. Bilateral injections of OXT in the dorsal hippocampus have been shown to significantly attenuate the neuroendocrine and behavioral responses to stress (Cohen et al., 2010). More interestingly, prior evidence has indicated that OXT can enhance long-term potentiation (LTP) at Schaffer collateralCA1 synapses and improve long-lasting spatial memory function during motherhood (Tomizawa et al., 2003); however, the molecular details of how it does so remain unclear. Moreover, a recent study has revealed that OXT could also act as a neurotrophic agent to stimulate cell proliferation and adult neurogenesis in the hippocampus even under conditions of stress or elevated glucocorticoids (Leuner et al., 2012).

The autonomously active protein kinase $\mathrm{C}$ isoform, protein kinase $\mathrm{M} \zeta(\mathrm{PKM} \zeta)$, has been found to be both necessary and sufficient for the maintenance of LTP and memory storage in the hippocampus (Sacktor et al., 1993; Ling et al., 2002; Pastalkova et al., 2006; Serrano et al., 2008; Hardt et al., 2010). Therefore, $\mathrm{PKM} \zeta$ could potentially mediate the enhancement effect of OXT on LTP. In this study, we provide novel evidence that OXT pro- 
motes the maintenance of LTP in hippocampal CA1 region via a $\mathrm{PKM} \zeta$-dependent mechanism. De novo PKM $\zeta$ protein synthesis at the synapses is required for OXT-induced enhancement of LTP. We further demonstrate that the OXT-regulated PKM $\zeta$ protein production relies on a PLC-dependent transactivation of epidermal growth factor receptor (EGFR), which in turn activates its downstream phosphatidylinositol 3 kinase (PI3K) and extracellular signal-regulated kinase 1/2 (ERK1/2) signaling, thereby stimulating dendritic translation of $\mathrm{PKM} \zeta$.

\section{Materials and Methods}

Hippocampal slice preparations and electrophysiology. All experimental procedures were conducted in adherence to the National Institutes of Health Guide for the Care and Use of Laboratory Animals (NIH Publication No. 80-23, revised 1996) and were approved by the Institutional Animal Care and Use Committee of National Cheng Kung University. Hippocampal slices were prepared from 28- to 35-d-old young female or male Sprague Dawley rats as described previously (Lin et al., 2006). In brief, rats were killed by decapitation under deep isoflurane anesthesia, and hippocampal slices (400 $\mu \mathrm{m})$ were prepared using Leica VT1200S vibrating blade microtome. The slices were placed in a storage chamber of artificial CSF (aCSF) oxygenated with $95 \% \mathrm{O}_{2} / 5 \% \mathrm{CO}_{2}$ and kept at room temperature $\left(23-25^{\circ} \mathrm{C}\right)$ for at least $1 \mathrm{~h}$ before recording. The composition of the aCSF solution was as follows (in mM): $117 \mathrm{NaCl}, 4.7 \mathrm{KCl}, 2.5 \mathrm{CaCl}_{2}, 1.2 \mathrm{MgCl}_{2}, 25 \mathrm{NaHCO}_{3}, 1.2$ $\mathrm{NaH}_{2} \mathrm{PO}_{4}$, and 11 glucose at $\mathrm{pH}$ 7.3-7.4.

For recording, one slice was transferred to a submerged recording chamber continually perfused with oxygenated aCSF at a flow rate of 2-3 $\mathrm{ml} / \mathrm{min}$ at $32.0 \pm 0.5^{\circ} \mathrm{C}$. The extracellular field potential recordings were made using an Axoclamp-2B amplifier (Molecular Devices). Microelectrodes were pulled from microfiber $1.0 \mathrm{~mm}$ capillary tubing on a Brown-Flaming electrode puller (Sutter Instruments). The responses were low-pass-filtered at $2 \mathrm{kHz}$, digitally sampled at $10 \mathrm{kHz}$, and analyzed using pCLAMP software (Version 8.0; Molecular Devices). Postsynaptic responses were evoked in CA1 stratum radiatum by stimulation of Schaffer collateral/commissural afferents at $0.033 \mathrm{~Hz}$ with a bipolar tungsten stimulating electrode. The stimulation strength was set to elicit response for which the amplitude was $30-40 \%$ of the maximum spike-free response. Field EP$\mathrm{SPs}$ (fEPSPs) were recorded with a glass pipette filled with $1 \mathrm{M} \mathrm{NaCl}(2-3 \mathrm{M} \Omega$ resistance) and the fEPSP slope was measured from $\sim 20-70 \%$ of the rising phase using a least-squares regression. LTP was induced by tetanic stimulation (TS), at the test pulse intensity, consisting of either one $1 \mathrm{~s}$ train of TS at $100 \mathrm{~Hz}$ or three $1 \mathrm{~s}$ trains of TS at $100 \mathrm{~Hz}$ separated by an intertrain interval of $5 \mathrm{~min}$. The magnitudes of LTP were averaged from the responses recorded during the last $10 \mathrm{~min}$ of the recording and normalized to $10 \mathrm{~min}$ of baseline before LTP induction. In some experiments, LTP was induced by one train of TS in the presence of $\mathrm{GABA}_{\mathrm{A}}$ receptor antagonist picrotoxin (PTX, 100 $\mu \mathrm{M})$. To reduce epileptiform activity during blockade of GABAergic inhibition, a surgical cut was made at the border between the CA1 and CA3 areas.

Preparation of synaptoneurosomes. Synaptoneurosomes were prepared by using a procedure adapted from the studies by Huttner et al. (1983) and Rao and Steward (1991). Briefly, hippocampal CA1 region was minced in ice-cold homogenization buffer $(0.32 \mathrm{M}$ sucrose, $0.5 \mathrm{~mm}$ EGTA, and $10 \mathrm{~mm}$ Tris; pH 7.4 with $\mathrm{KOH}$ ) and homogenized using a glass tissue grinder with a Teflon pestle. The homogenate was centrifuged at $1000 \times g$ for $10 \mathrm{~min}$ to remove nuclei and cell debris, and the supernatant was transferred to a new tube and centrifuged at $10,000 \times g$ for 30 min to generate a crude synaptoneurosomal fraction. The crude synaptoneurosomal fraction was washed once in HBS buffer [in mM: 10 HEPES-KOH, $142 \mathrm{NaCl}, 2.4 \mathrm{KCl}, 1 \mathrm{MgCl}_{2}, 5$ glucose, 0.1 EGTA, and 0.3 phenylmethylsulfonyl fluoride (PMSF); $\mathrm{pH}$ 7.5] and centrifuged once more at $13,000 \times g$ for $15 \mathrm{~min}$. It was then lysed in 10 volume of ice-cold $\mathrm{H}_{2} \mathrm{O}$ containing $0.3 \mathrm{~mm}$ PMSF for $30 \mathrm{~min}$, buffered with $1 \mathrm{~m}$ HEPES$\mathrm{KOH}, \mathrm{pH} 7.4$, and centrifuged at $25,000 \times g$ for $30 \mathrm{~min}$ to generate the synaptoneurosomal fraction. The synaptoneurosomal pellet was gently resuspended in the same buffer at a protein concentration of $2 \mathrm{mg} / \mathrm{ml}$. All procedures were performed at $4^{\circ} \mathrm{C}$.

Establishment and treatment of hippocampal neuronal cultures. Primary neuronal cultures were prepared from the hippocampi of embryonic day
18 Sprague Dawley rats as described previously (Balkowiec and Katz, 2002; Huang et al., 2010). Briefly, embryos were removed and their hippocampi were dissected out in ice-cold HBSS (Life Technologies) and freed from meninges. Tissues were enzymatically digested with $0.25 \%$ tryp$\sin$ (Sigma-Aldrich) for $15 \mathrm{~min}$ at $37^{\circ} \mathrm{C}$. Cells were disaggregated by trituration and plated on poly-L-lysine-coated Petri dishes in Neurobasal-A medium containing B27 serum-free supplement (Invitrogen), $0.5 \mathrm{~mm}$ L-glutamine, and antibiotics ( $50 \mathrm{U} / \mathrm{ml}$ penicillin and $50 \mu \mathrm{g} / \mathrm{ml}$ streptomycin). Cultures were incubated at $37^{\circ} \mathrm{C}$, under $5 \% \mathrm{CO}_{2} / 95 \%$ air and $90 \%$ relative humidity. Half of the growth medium was replaced every $3 \mathrm{~d}$. Very few glial cells were observed in these cultures (Huang et al., 2010).

Hippocampal neurons were maintained for $18-19 \mathrm{~d}$ in vitro (DIV) before treatment with OXT. Cultured hippocampal neurons were starved from B27 for $6 \mathrm{~h}$ before performing any treatment. Either 1-[4-[(1-acetyl-4-piperidinyl)oxy]-2-methoxybenzoyl]-4-(2-oxo-2 $H$-3,1-benzoxazin-1(4H)-yl)piperidine (L-371257), $\mathrm{N}$-(3-chlorophenyl)-6,7-dimethoxy-4-quinazolinanine hydrochloride (AG1478), 2-(4-morpholinyl)-8-phenyl-4 H-1-benzopyran4-one (LY294002), 1,4-diamino-2,3-dicyano-1,4-bis(o-aminophenylmercapto)butadiene (U0126), or rapamycin was applied $30 \mathrm{~min}$ before the addition of OXT (1 $\mu \mathrm{M})$ for $30 \mathrm{~min}$.

Western blotting. For each experimental group, homogenates from at least two slices were pooled. The microdissected CA1 subregions were homogenized in ice-cold Tris-HCl buffer solution (TBS; pH 7.4) containing a mixture of protein phosphatase and proteinase inhibitors (50 mu Tris- $\mathrm{HCl}, 100 \mathrm{~mm} \mathrm{NaCl}, 15 \mathrm{~mm}$ sodium pyrophosphate, $50 \mathrm{~mm}$ sodium fluoride, $1 \mathrm{~mm}$ sodium orthovanadate, $5 \mathrm{~mm}$ EGTA, 5 mM EDTA, $1 \mathrm{~mm}$ phenylmethylsulfonyl fluoride, $1 \mu \mathrm{M}$ microcystin-LR, $1 \mu \mathrm{M}$ okadaic acid, $0.5 \%$ Triton X-100, 2 mm benzamidine, $60 \mu \mathrm{g} / \mathrm{ml}$ aprotinin, and 60 $\mu \mathrm{g} / \mathrm{ml}$ leupeptin) to avoid dephosphorylation and degradation of proteins, and ground with a pellet pestle (Kontes Glassware). Samples were sonicated and spun down at $15,000 \times g$ at $4^{\circ} \mathrm{C}$ for $10 \mathrm{~min}$. The supernatant was then assayed for total protein concentration using Bio-Rad Bradford Protein Assay Kit. Each sample from tissue homogenate or synaptoneurosome was separated using $8 \%$ or $10 \%$ SDS-PAGE gel. Following the transfer on nitrocellulose or polyvinylidene fluoride membranes, blots were blocked in buffer solution containing 5\% milk and $0.1 \%$ Tween-20 in PBS (in mM: $124 \mathrm{NaCl}, 4 \mathrm{KCl}, 10 \mathrm{Na}_{2} \mathrm{HPO}_{4}$ and 10 $\mathrm{KH}_{2} \mathrm{PO}_{4} ; \mathrm{pH} 7.2$ ) for $1 \mathrm{~h}$ and then blotted for $2 \mathrm{~h}$ at room temperature with the antibodies that recognize PKM $\zeta$ (1:1000; Santa Cruz Biotechnology), pEGFR (Tyr1068; 1:1000; Cell Signaling Technology), pAkt (Ser473; 1:1000; Cell Signaling Technology), pAkt (Thr308; 1:1000; Cell Signaling Technology), pERK1/2 (Thr202/Tyr204; 1:1000; Cell Signaling Technology), or $\beta$-actin (1:2000, Sigma-Aldrich). It was then probed with HRP-conjugated secondary antibody for $1 \mathrm{~h}$ and developed using the enhanced chemiluminescence immunoblotting detection system (GE Healthcare), according to manufacturer's instructions. The immunoblots using phosphorylation site-specific antibodies were subsequently stripped and reprobed with the following antibodies: anti-Akt antibody (1:1000) or anti-ERK1/2 antibody (1:1000) that were purchased from Cell Signaling Technology, and anti-EGFR antibody $(1: 1000)$ that was obtained from Cell Signaling Technology. Immunoblots were analyzed by densitometry using Bio-profil BioLight PC software (Vulber Lourmat). Only film exposures that were not saturated were used for quantification analysis. The expression level of PKM $\zeta$ was evaluated relative to that for $\beta$-actin. Background correction values were subtracted from each lane to minimize the variability across membranes.

Drugs. All drugs were applied by manually switching the superfusate. Drugs were diluted from stock solutions just before application. L-371257, 1-[6-[[(17 $\beta)$-3-methoxyestra-1, 3, 5(10)-trien-17-yl]amino]hexyl]-1 $H$ pyrrole-2, 5-dione (U73122), 1-[6-[[(17 $\beta)$-3-methoxyestra-1,3,5(10)trien-17-yl]amino]hexyl]-2,5-pyrrolidinedione (U73343), cycloheximide, anisomycin, actinomycin-D, AG1478, $\alpha$-cyano-(4-hydroxy)dihydrocinnamonitrile (AG43), LY294002, U0126, (9S,10R,12R)-2,3,9,10,11,12-hexahydro-10-hydroxy-9-methyl-1-oxo-9,12-epoxy- $1 H$-diindolo[1,2,3-fg: $\left.3^{\prime}, 2^{\prime}, 1^{\prime}-k l\right]$ pyrrolo[3,4-i] [1,6] benzodiazocine-10-carboxylic acid methyl ester (K252a), rapamycin, ascomycin, and $N$-[(2R)-2-(hydroxamidocarbonylmethyl)-4-methylpentanoyl]-1-tryptophan methylamide (GM6001) were dissolved in dimethylsulfoxide (DMSO) stock solutions and then di- 
A
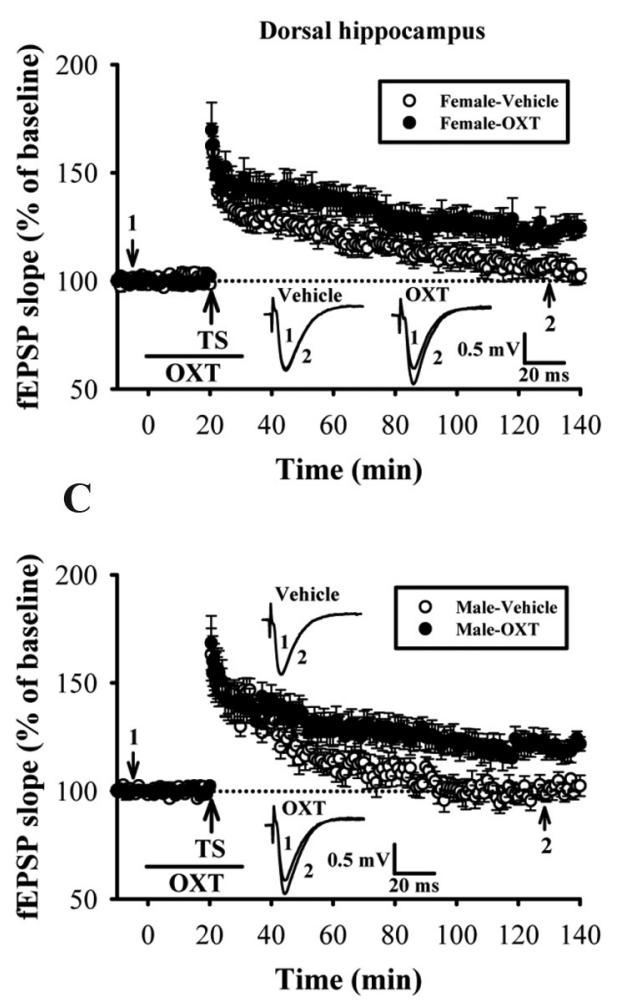

B
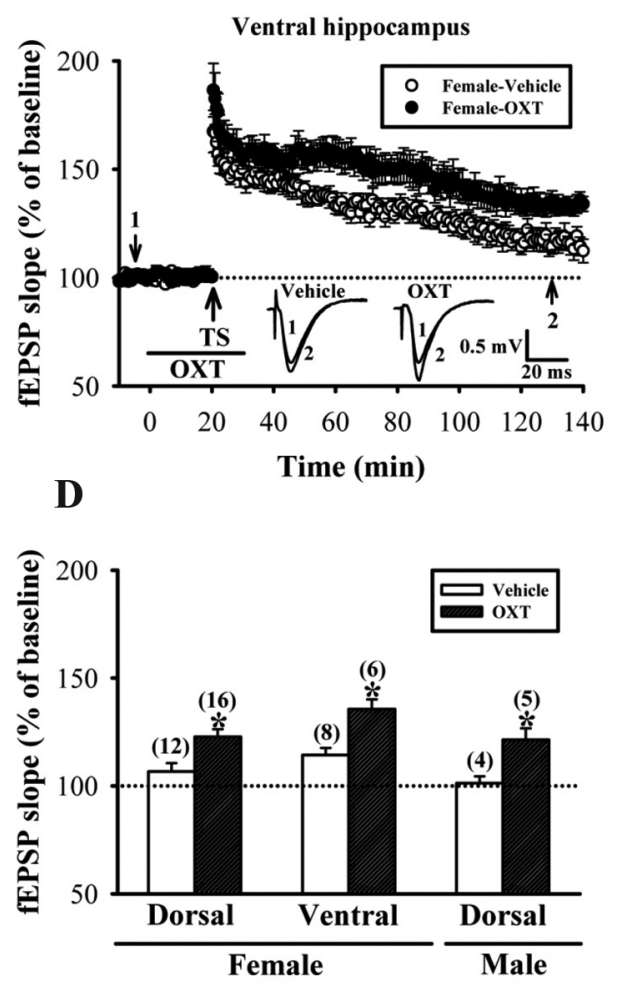

$\mathbf{E}$

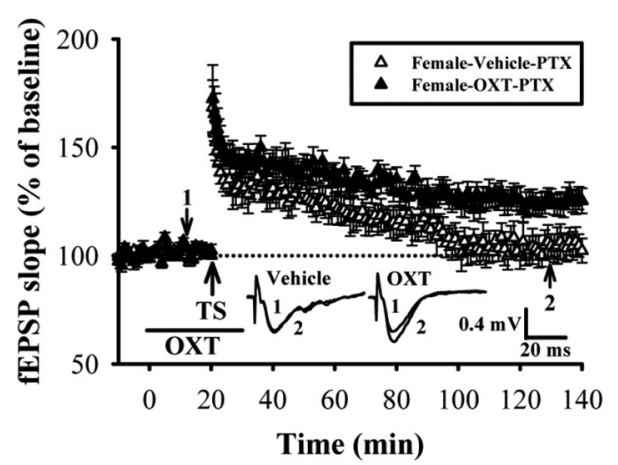

Figure 1. The effect of OXT on the induction of LTP in the CA1 region of rat hippocampal slices. $A$, Summary of experiments showing pairing one train of $1 \mathrm{~s}$ TS at $100 \mathrm{~Hz}$ with $0 X \mathrm{XX}(1 \mu \mathrm{M})$ application induced LTP of fEPSPs in slices from female rat dorsal hippocampus. Pairing TS with vehicle induced only a transient increase in synaptic strength. $\boldsymbol{B}$, Summary of experiments showing the effect of OXT treatment on the induction of LTP by one train of TS in slices from female rat ventral hippocampus. C, Summary of experiments showing the effect of OXT treatment on the induction of LTP by one train of TS in slices from male rat dorsal hippocampus. D, Summary histogram depicting the effect of oxytocin on the induction of LTP by one train of TS in slices from female or male hippocampus. The magnitudes of LTP were measured 110-120 min after TS. E, Summary of experiments showing the effect of OXT treatment on the induction of LTP by one train of TS in the presence of PTX (100 $\mu \mathrm{m}$ ) in slices from female rat dorsal hippocampus. Representative traces of fEPSPs were taken at the time indicated by number. Dash lines show level of baseline. The total number of animals examined is indicated by $n$ in parenthesis. Data are represented as mean \pm SEM. ${ }^{*} p<0.05$ compared with vehicle-treated group.

luted to their final concentration in aCSF just before application. The final concentration of DMSO in the perfusion medium did not exceed $0.1 \%$, which alone had no effect on basal synaptic transmission (Huang and Hsu, 2006). OXT, Myr-Ser-Ile-Tyr-Arg-Arg-Gly-Ala-Arg-Arg-Trp-Arg-Lys-Leu (ZIP), and Myr-Arg-Leu-Tyr-Arg-Lys-Ile-Trp-Arg-Ser-Ala-Gly-Arg (scrambled ZIP; Scr-ZIP) were dissolved in distilled water. The respective drug concentrations were selected on the basis of previously published and our pilot studies (Tomizawa et al., 2003; Chiu et al., 2005; Serrano et al., 2005; Huang and Hsu, 2006). U73343, ascomycin, K252a, PTX, and heparin were purchased from Sigma-Aldrich, OXT, L-371257, U73122, ZIP, Scr-ZIP, AG1478, rapamycin, cycloheximide, anisomycin, actinomycin D, U0126, and LY294002 were obtained from Tocris Cookson and AG43 and GM6001 were purchased from Calbiochem. The functional anti-EGF antibody (catalog \#MAB3214) was purchased from R\&D Systems.
Statistical analysis. The data for each experiment were normalized relative to baseline, and are presented as mean \pm SEM. Number of animals used is indicated by $n$. For LTP experiments, statistical analysis was performed using the non-parametric Mann-Whitney $U$ test. The significance of the difference between the groups was calculated by one-way ANOVA with Bonferroni's post hoc analyses or Student's $t$ test where appropriate. Probability values $(P)$ of $<0.05$ were considered to represent significant differences.

\section{Results}

OXT enhances the maintenance of LTP in the CA1 region of the hippocampus

We first confirmed the ability of OXT to promote LTP at Schaffer-collateral CA1 synapses in hippocampal slices from nul- 
liparous female rats (Tomizawa et al., 2003). LTP was induced by one $1 \mathrm{~s}$ train of TS at $100 \mathrm{~Hz}$, a protocol that normally produced only an early, short-term phase of LTP. In dorsal hippocampal slices without OXT application, one train of TS produced only a short-term synaptic potentiation that was stable for $\sim 1 \mathrm{~h}(50-60$ min after TS: $124.4 \pm 4.3 \%$ of baseline, $n=12$; $p<0.05$; MannWhitney $U$ test), but gradually declined to baseline by $2 \mathrm{~h}(110-$ 120 min after TS: $106.7 \pm 3.9 \%$ of baseline, $n=12 ; p>0.05$; Mann-Whitney $U$ test). When OXT ( $1 \mu \mathrm{M})$ was applied concomitantly with TS, the persistence of LTP was significantly enhanced (110-120 min after TS: $122.8 \pm 3.5 \%$ of baseline, $n=16 ; p<$ 0.05; Mann-Whitney $U$ test; Fig. $1 A, D$ ). Moreover, a similar result was also observed in slices prepared from the ventral portion of the hippocampus. In the presence of OXT, one train of TS induced a late-phase LTP, whereas in the absence of OXT, synaptic potentiation was returned to baseline by $2 \mathrm{~h}(110-120 \mathrm{~min}$ after TS: control, $114.3 \pm 3.3 \%$ of baseline, $n=8$; OXT, $135.6 \pm$ $4.5 \%$ of baseline, $n=6 ; p<0.05$; unpaired Student's $t$ test; Fig. $1 B, D)$. To test for the presence of sexually dimorphic effects of OXT on LTP, we compared the magnitude of LTP in dorsal hippocampal slices from male rats in the presence or absence of OXT. We found that, similar to those observed in slices from female rats, OXT significantly enhanced the maintenance of LTP in slices from male rats (110-120 min after TS: control, $101.3 \pm$ $3.2 \%$ of baseline, $n=4$; OXT, $121.4 \pm 5.3 \%$ of baseline, $n=5$; $p<0.05$; unpaired Student's $t$ test; Fig. $1 C, D)$. There was no significant difference in the effect of OXT on LTP between male and female rats $(p>0.05$; unpaired Student's $t$ test; Fig. $1 D)$. Furthermore, application of OXT alone $(1 \mu \mathrm{M})$ for 30 min had no significant effect on basal synaptic transmission in slices from female and male rats (data not shown). These results support the notion that OXT can enhance the maintenance of LTP in hippocampal CA1 region of both sexes.

OXTR agonists have been shown to enhance inhibitory synaptic transmission in hippocampal CA1 pyramidal neurons by activating interneurons in stratum pyramidale (Zaninetti and Raggenbass, 2000). Maternal OXT has also been reported to trigger a transient excitatory-to-inhibitory switch of GABAergic signaling in the fetal brain during delivery (Tyzio et al., 2006). Given that GABA-mediated inhibition is known to be an important regulatory factor during LTP induction in hippocampal CA1 region (Wigström and Gustafsson, 1983), one possibility is that OXT promotes LTP by altering the strength of GABAergic inhibition to CA1 pyramidal neurons. To test this possibility, we examined the effect of OXT on LTP in the presence of $\mathrm{GABA}_{\mathrm{A}}$ receptor antagonist PTX $(100 \mu \mathrm{M})$. We found that the enhancement of LTP by OXT was not significantly affected by PTX coapplication (110-120 min after TS: control, $103.2 \pm 5.7 \%$ of baseline, $n=5$; OXT, $126.4 \pm 5.4 \%$ of baseline, $n=5 ; p<0.05$; unpaired Student's $t$ test; Fig. $1 E$ ). These results suggest that the observed OXT-induced enhancement of hippocampal CA1 LTP is not caused by changes in $\mathrm{GABA}_{\mathrm{A}}$ receptor function.

The role of OXTR-mediated PLC activation on OXT-induced enhancement of LTP

The action of OXT is thought to be primarily mediated by its binding to OXTR, which activates the predominant downstream effector PLC mainly through the $\mathrm{G}_{\mathrm{q} / 11}$ (Gimpl and Fahrenholz, 2001). We therefore explored the role of OXTR-mediated PLC activation in OXT-induced enhancement of LTP. To this end, a selective OXTR antagonist L-371257 and a broad spectrum PLC blocker U73122 were used. As shown in Figure 2, $A$ and $C$, L-371257 dose-dependently prevented OXT-induced enhance-
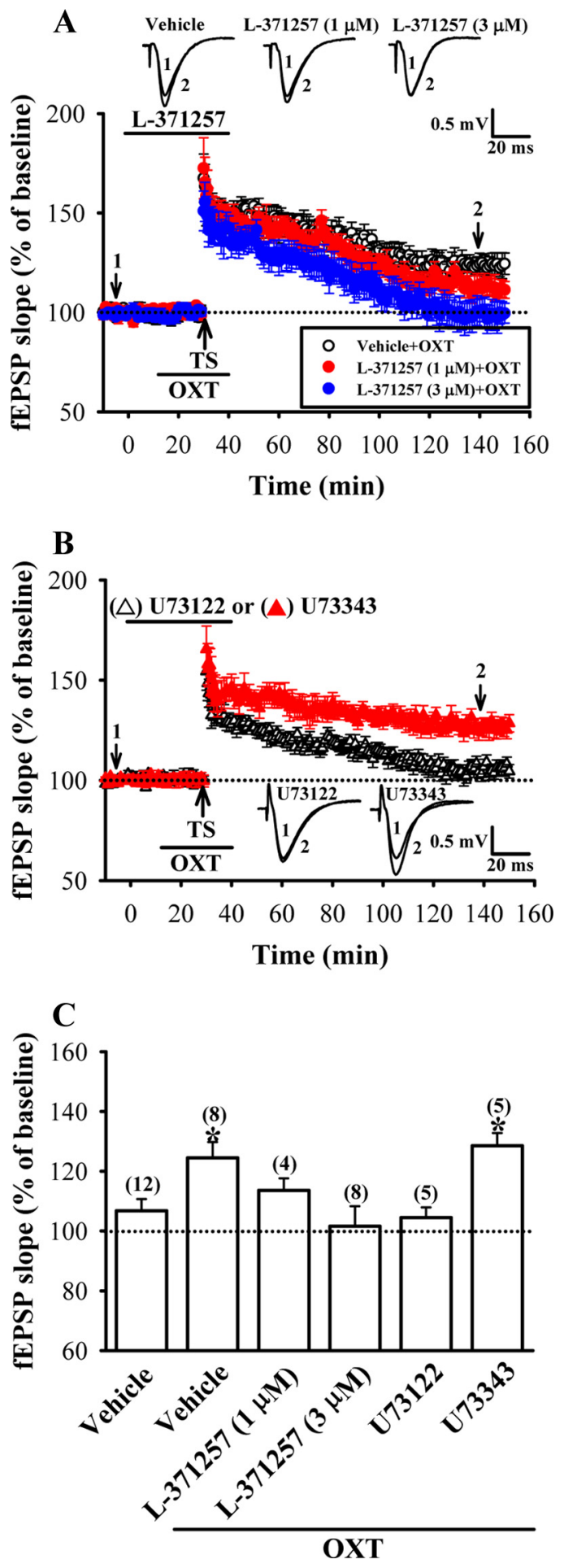

Figure 2. OXTR-coupled PLC signaling pathway mediates the enhancement of LTP by OXT. A, Summary of experiments showing pretreatment of hippocampal slices with OXTR antagonist L-371257 (1 or $3 \mu \mathrm{M}$ ) dose-dependently blocked 0XT (1 $\mu \mathrm{M})$-induced enhancement of LTP. B, Summary of experiments showing the enhancement of OXT on LTP was blocked by pretreatment of the hippocampal slices with the PLC inhibitor U73122 (10 $\mu \mathrm{M})$ but not by its inactive analog U73343 $(10 \mu \mathrm{M})$. C, Summary histogram depicting the effect of L-371257, U73122, and U73343 on OXT-induced enhancement of LTP in slices from female dorsal hippocampus. The magnitudes of LTP were measured 110-120 min after TS. Representative traces of fEPSPs were taken at the time indicated by number. Dash lines show level of baseline. The total number of animals examined is indicated by $n$ in parenthesis. Data are represented as mean \pm SEM. ${ }^{*} p<0.05$ compared with vehicletreated group. 


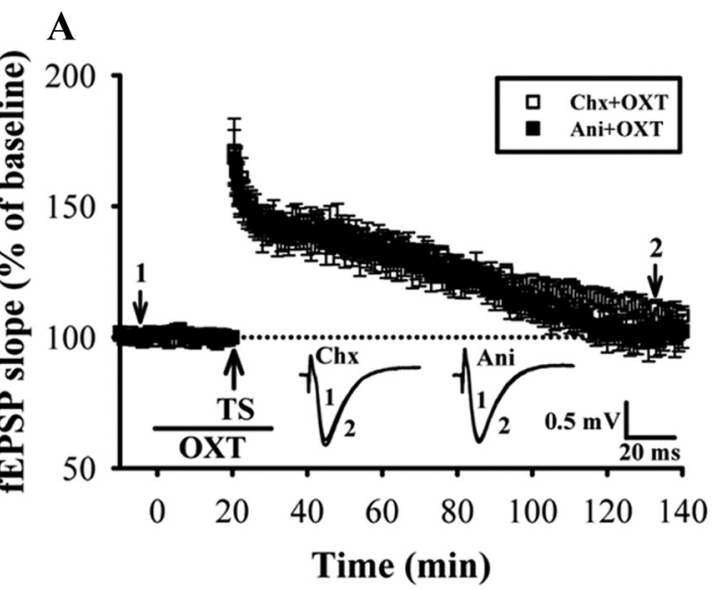

$\mathrm{C}$

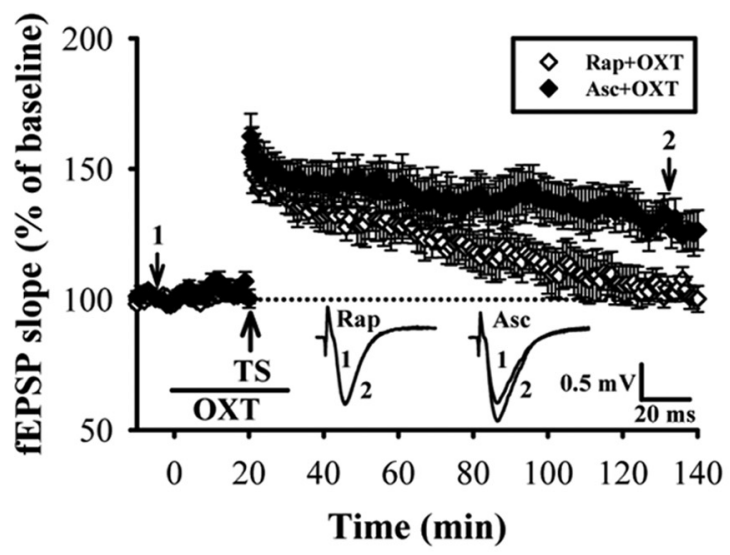



D

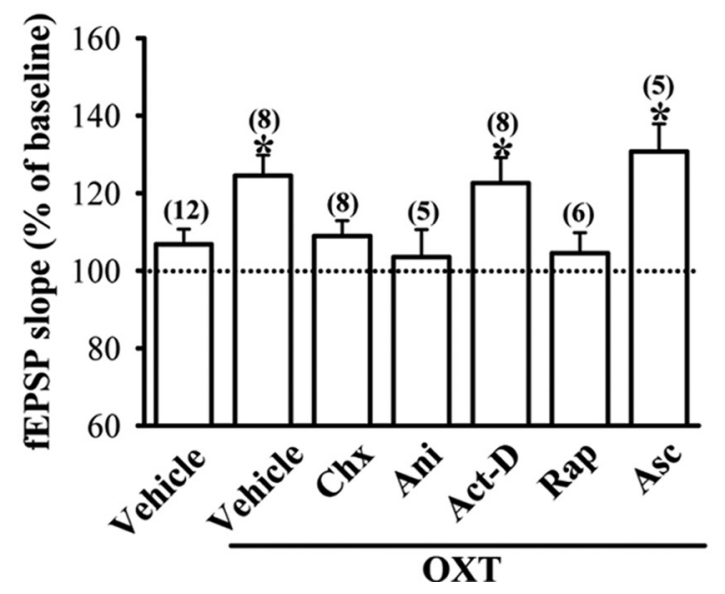

Figure 3. LTP induced by pairing one train of TS with OXT application requires de novo protein synthesis. $A$, Summary of experiments showing pretreatment of hippocampal slices with protein synthesis inhibitors, cycloheximide (Chx, $50 \mu \mathrm{m}$ ) or anisomycin (Ani, $20 \mu \mathrm{m}$ ) blocked OXT (1 $\mu \mathrm{m}$ )-induced enhancement of LTP. $\boldsymbol{B}$, Summary of experiments showing the effect of transcription inhibitor actinomycin D (Act-D, $25 \mu \mathrm{M}$ ) on OXT-induced enhancement of LTP in slices from female dorsal hippocampus. C, Summary of experiments showing the enhancement of OXT on LTP was blocked by pretreatment of the hippocampal slices with rapamycin (Rap, $200 \mathrm{~nm}$ ) but not by its inactive analog ascomycin (Asc, $200 \mathrm{~nm}$ ). D, Summary histogram depicting the effect of cycloheximide, anisomycin, actinomycin D, rapamycin, and ascomycin on OXT-induced enhancement of LTP in slices from female dorsal hippocampus. The magnitudes of LTP were measured $110-120$ min after TS. Representative traces of fEPSPs were taken at the time indicated by number. Dash lines show level of baseline. The total number of animals examined is indicated by $n$ in parenthesis. Data are represented as mean \pm SEM. ${ }^{*} p<0.05$ compared with vehicle-treated group.

ment of LTP [110-120 min after TS: vehicle + OXT, $124.5 \pm$ $5.3 \%$ of baseline, $n=8$; L-371257 $(1 \mu \mathrm{M})+$ OXT, $113.6 \pm 4.5 \%$ of baseline, $n=4$; L-371257 (3 $\mu \mathrm{M})+$ OXT, $101.6 \pm 6.7 \%$ of baseline, $n=8$; $p<0.05$; unpaired Student's $t$ test]. In addition, pretreatment of the hippocampal slices with U73122 (10 $\mu \mathrm{M})$, but not its inactive structural analog U73343 (10 $\mu \mathrm{M})$, completely blocked OXT-induced enhancement of LTP (110-120 min after TS: U73122, $104.5 \pm 3.4 \%$ of baseline, $n=5$; U73343, $128.5 \pm$ $4.3 \%$ of baseline, $n=5$; Fig. $2 B, C)$. These results suggest that the OXTR-mediated PLC activation is required for OXT-induced enhancement of LTP.

New protein synthesis is required for the enhancement of LTP by OXT

At hippocampal Schaffer collateral-CA1 synapses, the transition from early- to late-phase LTP requires gene expression and de novo protein synthesis (Stanton and Sarvey, 1984; Deadwyler et al., 1987; Nguyen et al., 1994). To investigate whether the enhancement of LTP by OXT depends upon protein and RNA synthesis, we tested the effects of two structurally different translational inhibitors, cycloheximide and anisomycin, and transcriptional inhibitor, actinomycin D, on OXT-induced enhancement of LTP. As shown in Figure 3, $A$ and $D$, pretreatment of hippocampal slices with either cycloheximide $(50 \mu \mathrm{M})$ or anisomycin $(20 \mu \mathrm{M})$, concentrations that have been shown to be effective in inhibiting $>80 \%$ of protein synthesis (Frey et al., 1988), completely blocked OXT-induced enhancement of LTP (110-120 min after TS: cycloheximide, $108.9 \pm 5.3 \%$ of baseline, $n=8$; anisomycin, $103.5 \pm 7.1 \%$ of baseline, $n=5)$. In contrast to the translational inhibitors, actinomycin D (25 $\mu \mathrm{M})$, a concentration that has been shown to block transcription by $>70 \%$ in hippocampal slices (Nguyen et al., 1994), pretreatment had no effect on the enhancement of LTP by OXT $(122.6 \pm 6.6 \%$ of baseline, $n=8 ; p>0.05$; unpaired Student's $t$ test; Fig. $3 B, D)$. In addition, none of the cycloheximide, anisomycin, or actinomycin $\mathrm{D}$ treatment alone had an effect per se on the maintenance of synaptic transmission following one $1 \mathrm{~s}$ train of TS at $100 \mathrm{~Hz}$ (data not shown). The synaptic potentiation returned to baseline within $2 \mathrm{~h}$ after TS. These results suggest that OXT-induced enhancement of LTP is dependent on protein synthesis, but not gene transcription.

The protein kinase mammalian target of rapamycin (mTOR) regulates multiple components of the translational machinery in mammalian cells (Brown and Schreiber, 1996), and mTOR activ- 
ity has been shown to be required for the induction of late-phase LTP in the hippocampus (Tang et al., 2002; Tsokas et al., 2005; Stoica et al., 2011). We therefore investigated whether the enhancement of LTP by OXT may occur through activation of mTOR-mediated regulation of protein synthesis, so the mTOR inhibitor rapamycin was used. As expected, pretreatment of the hippocampal slices with rapamycin $(200 \mathrm{nM})$, a concentration which has previously been shown to effectively block the expression of late-phase LTP and BDNF-induced synaptic potentiation in hippocampal CA1 region (Tang et al., 2002), but not its inactive analog ascomycin (200 nM), completely blocked OXTinduced enhancement of LTP (110-120 min after TS: rapamycin, $104.5 \pm 5.3 \%$ of baseline, $n=6$; ascomycin, $130.7 \pm 7.2 \%$ of baseline, $n=5$; Fig. $3 C, D$ ). Neither rapamycin nor ascomycin treatment alone affected the effect of TS on synaptic transmission (data not shown). Thus, mTOR-mediated regulation of protein synthesis is required for the enhancement of LTP by OXT.

\section{Local dendritic PKM $\zeta$ synthesis is crucial for OXT-induced enhancement of LTP}

What kind of protein biosynthesis could be responsible for mediating the enhancement of LTP by OXT? Because translation of the dendritically localized $\mathrm{PKM} \zeta$ mRNA is importantly involved in the maintenance of late-phase LTP (Muslimov et al., 2004; Kelly et al., 2007), we therefore analyzed the contribution of $\mathrm{PKM} \zeta$ in OXT-induced enhancement of LTP by using a selective, cell-permeable PKM $\zeta$ inhibitor ZIP (Laudanna et al., 1998; Ling et al., 2002). We found that pretreatment of the hippocampal slices with ZIP at $2 \mu \mathrm{M}$, a concentration sufficient to inhibit $\mathrm{PKM} \zeta$-mediated synaptic potentiation (Serrano et al., 2005), but not its inactive scrambled peptide (Scr-ZIP, $2 \mu \mathrm{M}$ ), completely blocked OXT-induced enhancement of LTP (110-120 min after TS: ZIP, $104.2 \pm 5.5 \%$ of baseline, $n=5$; Scr-ZIP, $128.6 \pm 6.2 \%$ of baseline, $n=5$; Fig. $4 A$ ). Neither ZIP nor Scr-ZIP treatment alone affected the effect of TS on synaptic transmission (data not shown). If $\mathrm{PKM} \zeta$ is required for the maintenance of OXTinduced LTP, the established LTP should be reversed when ZIP is applied during its maintenance phase. Consistent with this idea, when ZIP $(2 \mu \mathrm{M})$ was applied $80 \mathrm{~min}$ after conjoint OXT and one train of TS, synaptic potentiation returned toward baseline levels (110-120 min after TS: $104.6 \pm 4.7 \%$ of baseline, $n=5$; Fig. $4 B$ ). Thus, the persistent activity of $\mathrm{PKM} \zeta$ maintains OXT-induced enhancement of LTP.

To further confirm the role of $\mathrm{PKM} \zeta$ in the enhancement of LTP by OXT, in another set of experiments, we examined the effect of OXT on PKM $\zeta$ expression using Western blot analysis. Incubation of hippocampal slices with OXT $(1 \mu \mathrm{M})$ for $10-60$ min resulted in a time-dependent increase in levels of PKM $\zeta$ protein in the whole tissue lysates of hippocampal CA1 region (Fig. 5A). Because application of OXT $(1 \mu \mathrm{M})$ for $30 \mathrm{~min}$ consistently increased $\mathrm{PKM} \zeta$ expression, we chose this treatment protocol for all subsequent experiments designed to identify the mechanisms underlying this event. As shown in Figure 5B, application of one train of TS in the presence of OXT $(1 \mu \mathrm{M})$ significantly increased PKM $\zeta$ levels. A significant increase in $\mathrm{PKM} \zeta$ levels was also seen in slices stimulated with $\mathrm{KCl}(50 \mathrm{~mm})$ for 3 min or three trains of TS (Fig. 5B). In addition, OXT-induced increases in $\mathrm{PKM} \zeta$ expression were completely blocked by cycloheximide $(50 \mu \mathrm{M})$ and anisomycin $(20 \mu \mathrm{M})$, respectively, but not by actinomycin D $(25 \mu \mathrm{M})$ (Fig. $5 C$ ), thus confirming that OXT stimulates PKM $\zeta$ expression through a translationdependent mechanism. None of the actinomycin D, cyclohexi-
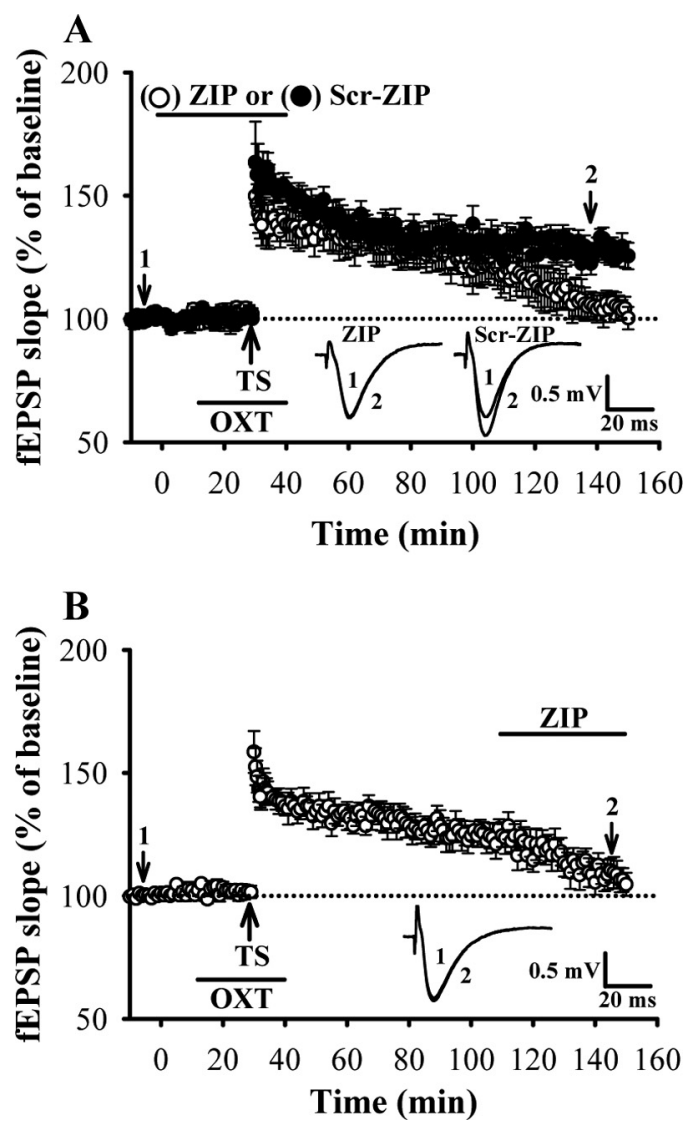

Figure 4. PKM $\zeta$ is critical for OXT-induced enhancement of LTP. $A$, Summary of experiments showing the enhancement of OXT on LTP was blocked by pretreatment of the hippocampal slices with the PKM $\xi$ inhibitor ZIP ( $2 \mu \mathrm{M})$ but not its inactive analog scrambled ZIP (Scr-ZIP, 2 $\mu \mathrm{M})$. $\boldsymbol{B}$, Summary of experiments showing ZIP $(2 \mu \mathrm{m})$ reversed synaptic potentiation when applied 80 min after conjoint OXT and one train of TS in slices from female dorsal hippocampus. Representative traces of fEPSPs were taken at the time indicated by number. Dash lines show level of baseline. Data are represented as mean \pm SEM.

mide, or anisomycin treatments alone had an effect on basal levels of PKM $\zeta$ (Fig. 5C).

Although there is evidence that PKM $\zeta$ mRNA can be translated in hippocampal CA1 pyramidal cell dendrites (Muslimov et al., 2004; Kelly et al., 2007), the major site of protein synthesis is the cell body. To specifically explore the presence and the possible synthesis of $\mathrm{PKM} \zeta$ protein from the synaptic fractions, we prepared synaptoneurosome, a biochemical preparation that enriches for synaptic fractions (Hollingsworth et al., 1985), from microdissected CA1 subfield samples. We first validated whether $\mathrm{PKM} \zeta \mathrm{mRNA}$ located to the synaptic compartment could be under the same translational control as we detected in intact slices. As shown in Figure 5D, an increase in $\mathrm{PKM} \zeta$ protein expression was observed after OXT $(1 \mu \mathrm{M})$ treatment for $30 \mathrm{~min}$. Pretreatment of the synaptoneurosomes with rapamycin (200 nM) completely blocked this event, whereas ascomycin had no effect on OXT-induced increases in PKM $\zeta$ protein expression. Neither rapamycin nor ascomycin treatments alone had an effect on basal $\mathrm{PKM} \zeta$ protein levels (Fig. 5D). These results suggest that OXTinduced increases in $\mathrm{PKM} \zeta$ expression occurs, at least in part, in dendrites.

Transactivation of EGFR is required for OXT-induced enhancement of LTP and PKM $\zeta$ protein synthesis A series of studies were performed to identify the cellular mechanisms underlying the OXT-induced increases in PKM $\zeta$ expres- 
A

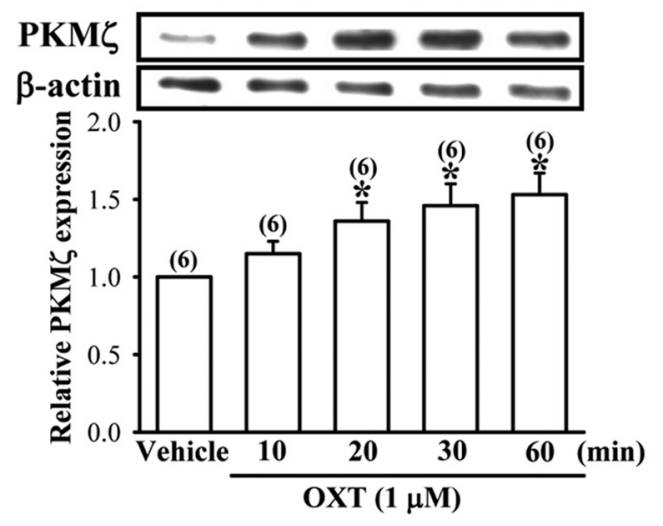

C
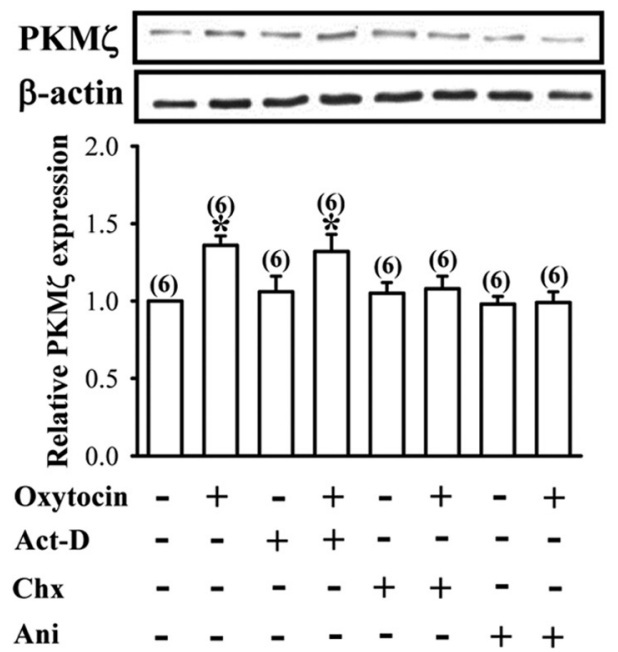

B
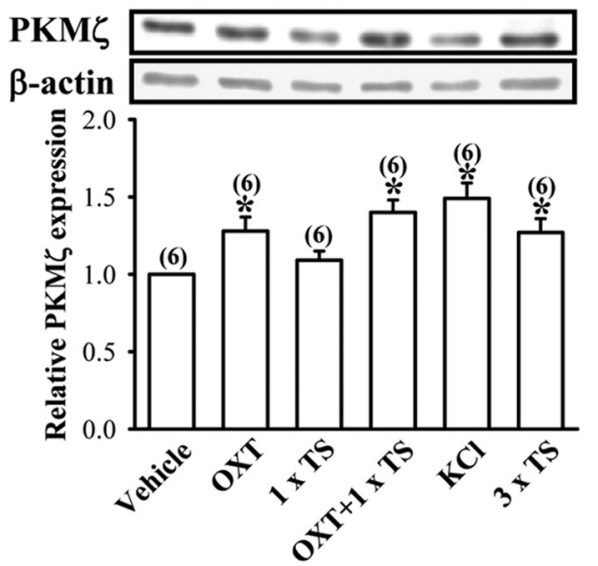

D
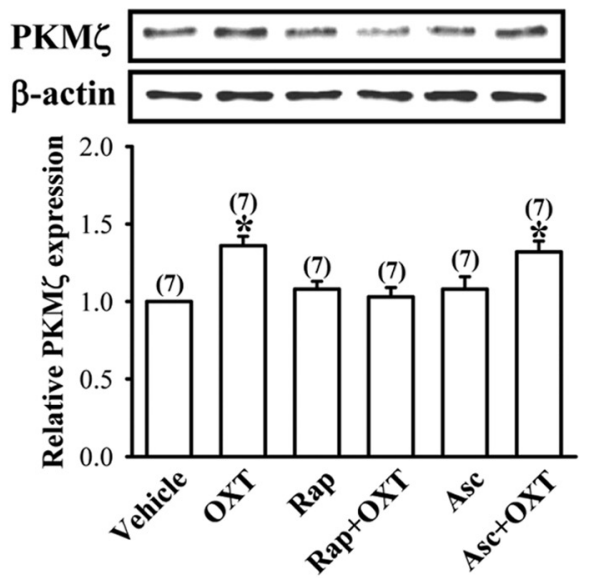

Figure 5. OXT stimulates PKM $\xi$ synthesis in hippocampal CA1 region. $A$, Representative immunoblot and summary histogram showing $0 \mathrm{XT}(1 \mu \mathrm{M})$ time-dependently induces increases in PKM $\xi$ expression in the whole tissue lysates of hippocampal CA1 region. $B$, Representative immunoblot and summary histogram showing the effect of vehicle, OXT (1 $\mu \mathrm{M})$, one train of TS, KCI ( $50 \mathrm{mM})$, and three trains of TS treatment on the expression of PKM $\xi$ in the whole tissue lysates of hippocampal CA1 region. C, Representative immunoblot and summary histogram showing 0XT (1 $\mu \mathrm{M}$ )-induced increases in PKM $\xi$ expression were blocked by pretreatment with cycloheximide (Chx, $50 \mu \mathrm{m}$ ) or anisomycin (Ani, $20 \mu \mathrm{m}$ ) but not by actinomycin D (Act-D, $25 \mu \mathrm{M})$. D, Representative immunoblot and summary histogram showing pretreatment of the synaptoneurosomes with rapamycin (Rap, $200 \mathrm{~nm}$ ) but not ascomycin (Asc, $200 \mathrm{~nm}$ ) blocked 0XT (1 $\mu \mathrm{m}$ )-induced increases in PKM $\xi$ synthesis. The total number of experiments is indicated by $n$ in parenthesis. Data are represented as mean \pm SEM. ${ }^{*} p<0.05$ compared with vehicle-treated group.

sion in the synaptoneurosomes. To confirm the involvement of OXTR-mediated PLC activation, we examined the effect of OXT in the presence of OXTR antagonist L-371257 or PLC blocker U73122. We found that pretreatment of the synaptoneurosomes with L-371257 $(3 \mu \mathrm{M})$ or U73122 $(10 \mu \mathrm{M})$ completely blocked OXT $(1 \mu \mathrm{M})$-induced increases in PKM $\zeta$ protein synthesis (Fig. $6 A, B)$. Neither L-371257 nor U73122 treatment alone had an effect on basal levels of PKM $\zeta$ protein (Fig. $6 A, B$ ).

Because OXT has been shown to transactivate EGFR tyrosine kinase in both PHM1 immortalized human myometrial cells (Zhong et al., 2003) and bovine endometrial epithelial cells (Krishnaswamy et al., 2010), we therefore examined whether activation of OXTR could transactivate EGFR and subsequently stimulate $\mathrm{PKM} \zeta$ protein synthesis. As expected, we found that pretreatment of the synaptoneurosomes with a tyrophostin AG1478 (1 $\mu \mathrm{M})$, a selective inhibitor of EGFR (Levitzki and Gazit, 1995), completely blocked OXT (1 $\mu \mathrm{M})$-induced increases in $\mathrm{PKM} \zeta$ protein synthesis (Fig. $6 C)$. However, K252a (0.2 $\mu \mathrm{M})$, a potent inhibitor of the Trk family of receptor tyrosine kinases (Tapley et al., 1992), did not alter the effect of OXT (Fig. 6D), suggesting some specificity of OXTR-induced transactivation of EGFR. Because PI3K and ERK1/2 are two major downstream effectors activated by EGFR, we next examined the possible role of PI3K and ERK1/2 in OXT-induced increases in $\mathrm{PKM} \zeta$ protein synthesis. Accordingly, we pretreated the synaptoneurosomes with PI3K inhibitor LY294002 $(20 \mu \mathrm{M})$ or MAPK kinase inhibitor U0126 $(10 \mu \mathrm{M})$ and found that both of them effectively blocked OXT $(1 \mu \mathrm{M})$-induced increases in PKM $\zeta$ protein synthesis (Fig. $6 C)$. Moreover, consistent with its ability to inhibit OXT-induced increases in $\mathrm{PKM} \zeta$ protein synthesis in the synaptoneurosomes, AG1478 (1 $\mu \mathrm{M})$ also blocked OXT-induced enhancement of LTP (110-120 min after HFS: rapamycin, $106.8 \pm 5.6 \%$ of baseline, $n=5$; Fig. 6 E). AG1478 treatment alone had no effect on synaptic transmission before or after TS (data not shown). These results indicate that EGFR serves as an important effector in a signaling pathway connecting OXTR to $\mathrm{PKM} \zeta$ protein synthesis.

To further characterize the transactivation of EGFR by OXTR, we measured the tyrosine phosphorylation of EGFR by using a phospho-specific antibody that recognizes the autophosphorylation of EGFR at Tyr1068 in the synaptoneurosomes. We found 
A
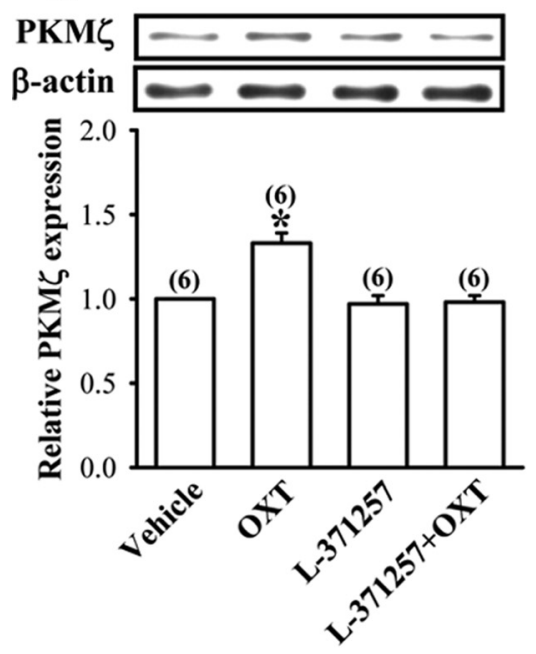

D



B
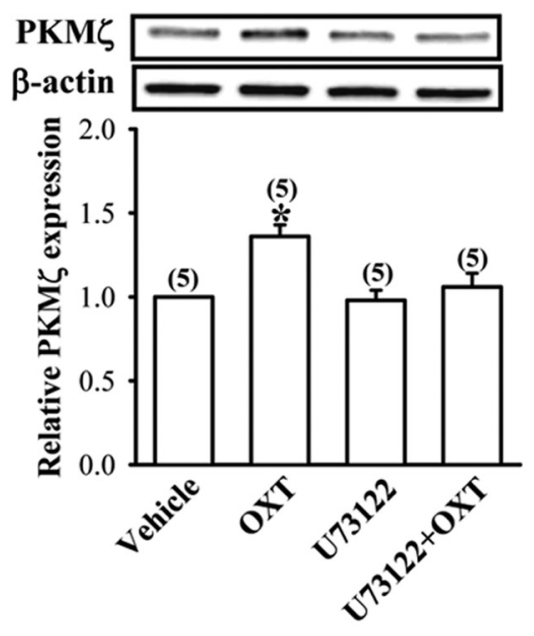

E



C

РКМ $\zeta \square-\cdots-\cdots-$

$\beta$-actin $-\infty-\infty-\infty$

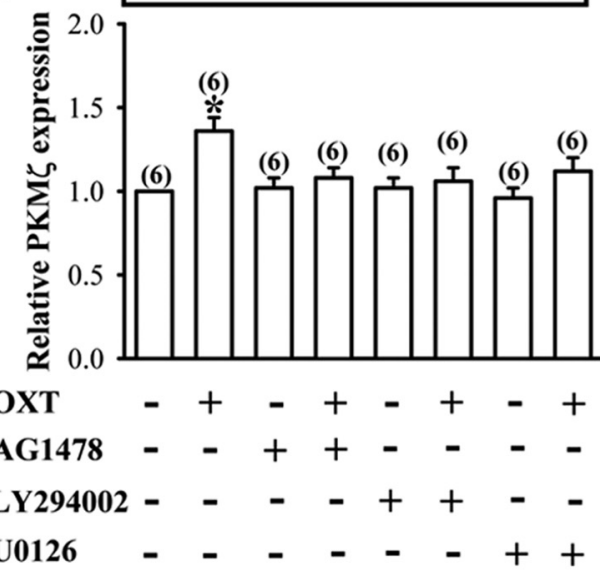

Figure 6. Involvement of OXTR/PLC and EGFR transactivation in OXT-induced increases in PKM $\xi$ synthesis. $\boldsymbol{A}, \boldsymbol{B}$, Representative immunoblot and summary histogram showing pretreatment of the synaptoneurosomes with OXTR antagonist L-371257 (3 $\mu \mathrm{M})$ or PLC blocker U73122 (10 $\mu \mathrm{M})$ blocked OXT (1 $\mu \mathrm{M})$-induced increases in PKM $\xi$ synthesis. $C$, Representative immunoblot and summary histogram showing OXT (1 $\mu \mathrm{M})$-induced increases in PKM $\xi$ expression in the synaptoneurosomes was blocked by pretreatment with EGFR inhibitor AG1478 (1 $\mu \mathrm{M})$, PI3K inhibitor LY294002 $(20 \mu \mathrm{M})$, or MAPK kinase inhibitor U0126 $(10 \mu \mathrm{M})$. D, Summary of experiments showing pretreatment of hippocampal slices with AG1478 $(1 \mu \mathrm{M})$ blocked 0XT (1 $\mu \mathrm{M})$-induced enhancement of LTP. Representative traces of fEPSPs were taken at the time indicated by number. Dash lines show level of baseline. $\boldsymbol{E}$, Representative immunoblot and summary histogram showing OXT (1 $\mu \mathrm{M})$-induced increases in PKM $\xi$ expression were not affected by pretreatment of the synaptoneurosomes with Trk family of receptor tyrosine kinase inhibitor K252a (0.2 $\mu \mathrm{M})$. The total number of experiments is indicated by $n$ in parenthesis. Data are represented as mean \pm SEM. ${ }^{*} p<0.05$ compared with vehicle-treated group.

that OXT $(1 \mu \mathrm{M})$ stimulated a rapid increase in the tyrosine phosphorylation of EGFR, reaching a maximum within $10 \mathrm{~min}$ and remaining elevated for at least $25 \mathrm{~min}$ (Fig. $7 A$ ). The increase in tyrosine phosphorylation was blocked by pretreatment with L-371257 (3 $\mu \mathrm{M})$, U73122 (10 $\mu \mathrm{M})$, or AG1478 (1 $\mu \mathrm{M})$ (Fig. $7 B-$ $D)$, supporting a signaling model that OXTR transactivates EGFR through a PLC-dependent mechanism.

To investigate whether OXT stimulates PI3K activity, we indirectly monitored the activation of PI3K by measuring the phosphorylation of its downstream target Akt at both Thr308 and Ser473 sites (Franke et al., 1995). We found that OXT (1 $\mu \mathrm{M})$ treatment significantly increased the level of phosphorylated Akt, which was blocked by AG1478 pretreatment (1 $\mu \mathrm{M})$ (Fig. 7E). Likewise, OXT $(1 \mu \mathrm{M})$ also induced a significant increase in the phosphorylation of ERK1/2, and this increase was also blocked by AG1478 $(1 \mu \mathrm{M})$ pretreatment (Fig. $7 F)$. These results indicate that activation of OXTR may lead to transactivation of EGFR and its PI3K and ERK1/2 downstream signaling pathways. Because a close interdependence between PI3K and ERK1/2 signaling pathways have been reported in a wide variety of cell types including neurons (Chandler et al., 2001; Perkinton et al., 2002; Yang et al., 2008), we therefore asked whether there exists a crosstalk between the PI3K and ERK1/2 signaling pathways in mediating OXT-induced increases in PKM $\zeta$ protein synthesis. We found that pretreatment with PI3K inhibitor LY294002 (20 $\mu \mathrm{M})$ caused a significant reduction of OXT-induced ERK1/2 phosphorylation (Fig. $7 G$ ). In contrast, OXT-induced Akt phosphorylation was not significantly altered by MAPK kinase inhibitor U0126 $(10 \mu \mathrm{M}$; Fig. $7 \mathrm{H}$ ), indicating that PI3K may act upstream of ERK1/2 to mediate OXT regulation.

To further delineate whether the crosstalk between OXTR and EGFR is mediated by extracellular release of EGFR ligands, we used three different approaches. First, we pretreated the synaptoneurosomes with the functional anti-EGF antibody at $10 \mu \mathrm{g} /$ $\mathrm{ml}$, a concentration sufficient to inhibit EGF (20 ng/ml)-induced tyrosine phosphorylation of EGFR, for $30 \mathrm{~min}$ before OXT (1 $\mu \mathrm{M})$ 
A
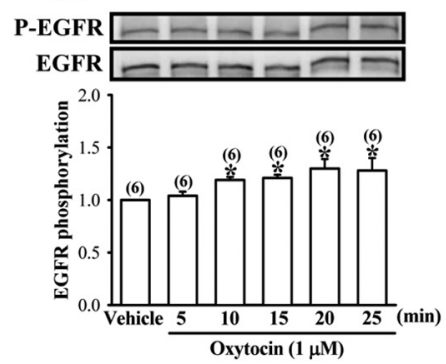

E
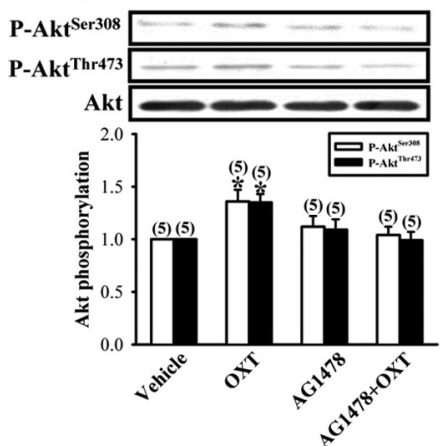

B
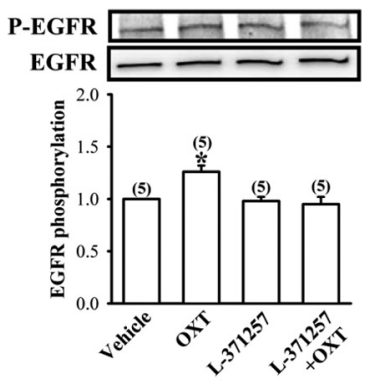

F

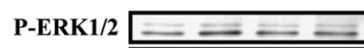

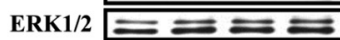

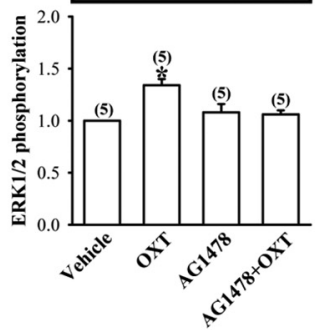

C
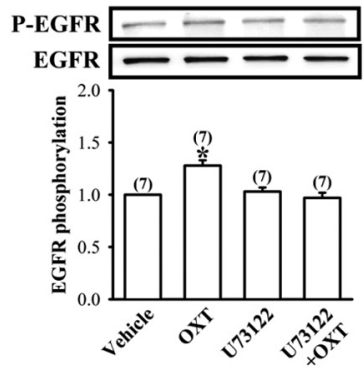

G



ERK1/2 $\overline{\square=\square}$

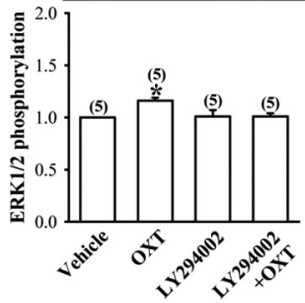

D
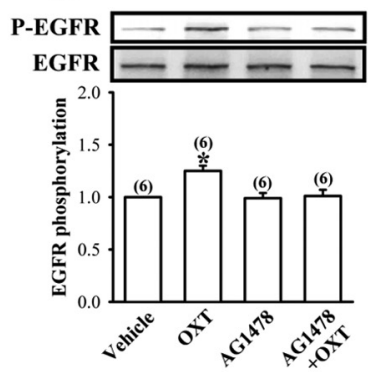

H

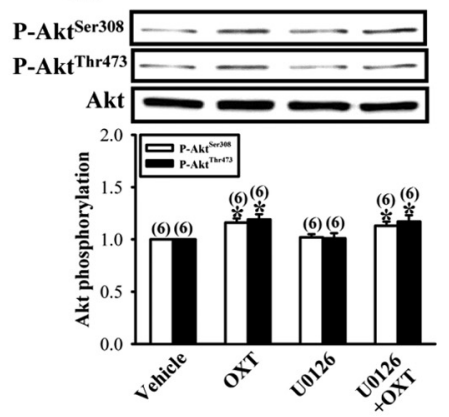

Figure 7. OXT stimulates EGFR-dependent PI3K and ERK1/2 activation in the synaptoneurosomes. $A$, Representative immunoblot and summary histogram showing $0 \mathrm{XT}$ ( $1 \mu \mathrm{m}$ ) induces increases in tyrosine phosphorylation of EGFR in a time-dependent manner. $\boldsymbol{B}-\boldsymbol{D}$, Representative immunoblot and summary histogram showing pretreatment of the synaptoneurosomes with $\mathrm{L}-371257$ (3 $\mu \mathrm{M})$, U73122 (10 $\mu \mathrm{m})$, or AG1478 (1 $\mu \mathrm{m})$ blocked OXT (1 $\mu \mathrm{m})$-induced increases in EGFR tyrosine phosphorylation. $\boldsymbol{E}$, Representative immunoblot and summary histogram showing pretreatment of the synaptoneurosomes with AG1478 (1 $\mu \mathrm{m})$ blocked OXT (1 $\mu \mathrm{m})$-induced increases in Akt phosphorylation at both Thr308 and Ser473 sites. $\boldsymbol{F}$, Representative immunoblot and summary histogram showing pretreatment of the synaptoneurosomes with AG1478 (1 $\mu \mathrm{m})$ blocked OXT (1 $\mu \mathrm{m})$-induced increases in ERK1/2 phosphorylation. G, Representative immunoblot and summary histogram showing pretreatment of the synaptoneurosomes with LY294002 (20 $\mu \mathrm{m})$ significantly inhibited 0XT (1 $\mu \mathrm{m})$-induced increases in ERK1/2 phosphorylation. $\boldsymbol{H}$, Representative immunoblot and summary histogram showing pretreatment of the synaptoneurosomes with U0126 (10 $\mu \mathrm{m})$ had no effect on $0 X \mathrm{XT}(1 \mu \mathrm{m})$-induced increases in Akt phosphorylation. Inhibitors were applied $30 \mathrm{~min}$ before the addition of OXT for $30 \mathrm{~min}$. The total number of experiments is indicated by $n$ in parenthesis. Data are represented as mean $\pm \mathrm{SEM}$. ${ }^{*} p<0.05$ compared with vehicle-treated group.

application, and found that OXT-induced EGFR tyrosine phosphorylation remained normal (Fig. 8A). Because exogenously applied heparin has been shown to effectively inhibit EGFR transactivation by competing with cell surfaceassociated heparin sulfate proteoglycans for HB-EGF binding (Raab and Klagsbrun, 1997; Kalmes et al., 2000), we therefore tested whether HB-EGF is required for OXT-induced EGFR transactivation by pretreatment of the synaptoneurosomes with heparin $(50 \mu \mathrm{g} / \mathrm{ml})$, a concentration that has been shown to effectively block angiotensin-II or HB-EGF-induced EGFR tyrosine phosphorylation (Chiu et al., 2005). We found no changes in OXT-induced EGFR tyrosine phosphorylation in the presence of heparin (Fig. $8 \mathrm{~B}$ ). Because the activity of matrix metalloproteinase (MMP) has been shown to be required to mediate extracellular release of EGFR ligands (Prenzel et al., 1999; Chiu et al., 2005), we examined the influence of a broadspectrum MMP inhibitor GM6001 (10 $\mu \mathrm{M})$, a concentration that has been shown to block angiotensin-II-induced EGFR tyrosine phosphorylation (Chiu et al., 2005), on OXT-induced EGFR tyrosine phosphorylation. As shown in Figure 8C, OXTinduced tyrosine phosphorylation of EGFR was not significantly altered by pretreatment with GM6001. Together, these findings suggest that OXT-induced EGFR transactivation does not require extracellular release of EGFR ligands.

We next investigated whether OXT-induced increases in $\mathrm{PKM} \zeta$ protein synthesis also occurred in the cultured hippocampal neurons. We first confirmed that the cultured hippocampal neurons faithfully reproduced the increased expression of $\mathrm{PKM} \zeta$ protein to OXT treatment that was observed in acute slice and synaptoneurosomal preparations (Fig. 9A). Consistently, pretreatment of the cultured preparations with L-371257 (3 $\mu \mathrm{M})$ or AG1478 (1 $\mu \mathrm{M})$ completely blocked OXT ( $1 \mu \mathrm{M})$-induced increases in PKM $\zeta$ protein synthesis. In addition, the effect of OXT on PKM $\zeta$ protein synthesis was blocked by pretreatment of the cultured hippocampal neurons with rapamycin (200 nM), LY294002 (20 $\mu \mathrm{M})$, or U0126 $(10 \mu \mathrm{M})$, respectively (Fig. 9B). These results strengthen our hypothesis that $\mathrm{PKM} \zeta$ synthesis is upregulated by OXT through a mechanism that involves EGFR transactivation and the PI3K/ERK1/2/mTOR signaling pathway.

\section{Endogenous OXT contributes to the maintenance of the} late-phase but not early-phase of LTP

We finally examined the possible contribution of endogenous OXT in the maintenance of LTP. To this end, late-phase LTP was induced by three $1 \mathrm{~s}$ trains of TS at $100 \mathrm{~Hz}$ separated by 5 min in the presence of OXTR antagonist L-371257 ( $1 \mu \mathrm{M})$. In the control slice, TS produced synaptic potentiation that was stable for $>2 \mathrm{~h}(110-120 \mathrm{~min}$ after last TS: $136.8 \pm 6.7 \%$ of baseline, $n=5$ ). In the slices incubated with L-371257, however, TS produced synaptic potentiation that was stable for $\sim 1$ h (50-60 min after last TS: $132.6 \pm 6.8 \%$ of baseline, $n=6$ ) and then gradually declined to baseline by $2 \mathrm{~h}$ after TS (110120 min after last TS: $110.2 \pm 6.2 \%$ of baseline, $n=6$; Fig. 10), suggesting a crucial role for endogenous OXT in the maintenance of late-phase LTP. 
A

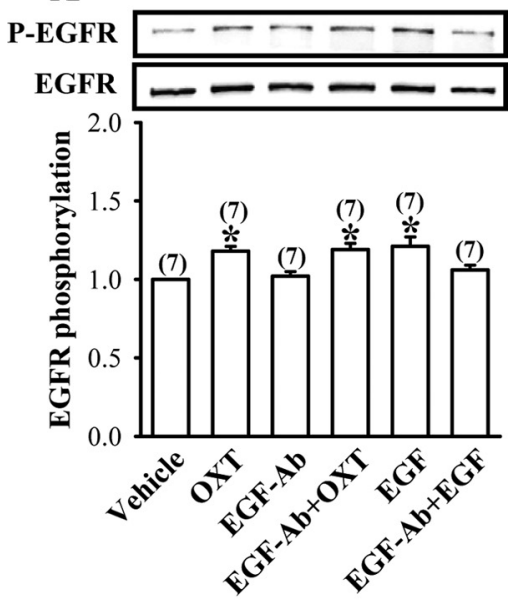

B
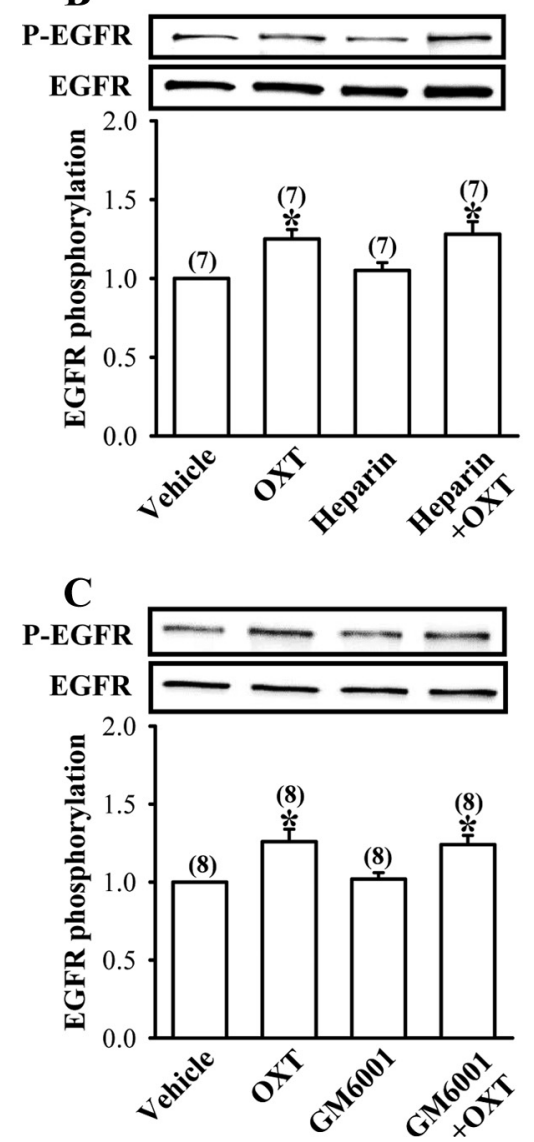

Figure 8. OXT-induced EGFR transactivation does not require extracellular release of EGFR ligands or MMP activity. $\boldsymbol{A}$, Representative immunoblot and summary histogram showing OXT (1 $\mu \mathrm{m})$-induced increases in EGFR tyrosine phosphorylation in the synaptoneurosomes was not affected by pretreatment with a functional anti-EGF antibody (EGF-Ab) at a concentration of $10 \mu \mathrm{g} / \mathrm{ml}$, which was sufficient to completely block EGF (20 $\mathrm{ng} / \mathrm{ml})$-induced tyrosine phosphorylation of EGFR. $\boldsymbol{B}$, Representative immunoblot and summary histogram showing pretreatment of the synaptoneurosomes with heparin (50 $\mu \mathrm{g} / \mathrm{ml})$ had no effect on OXT (1 $\mu \mathrm{M})$-induced increases in EGFR tyrosine phosphorylation. C, Representative immunoblot and summary histogram showing OXT (1 $\mu \mathrm{m})$-induced increases in EGFR tyrosine phosphorylation in the synaptoneurosomes was not affected by pretreatment with MMP inhibitor GM6001 (10 $\mu \mathrm{M})$. Inhibitors were applied $30 \mathrm{~min}$ before the addition of OXT for $30 \mathrm{~min}$. The total number of experiments is indicated by $n$ in parenthesis. Data are represented as mean \pm SEM. ${ }^{*} p<0.05$ compared with vehicletreated group.
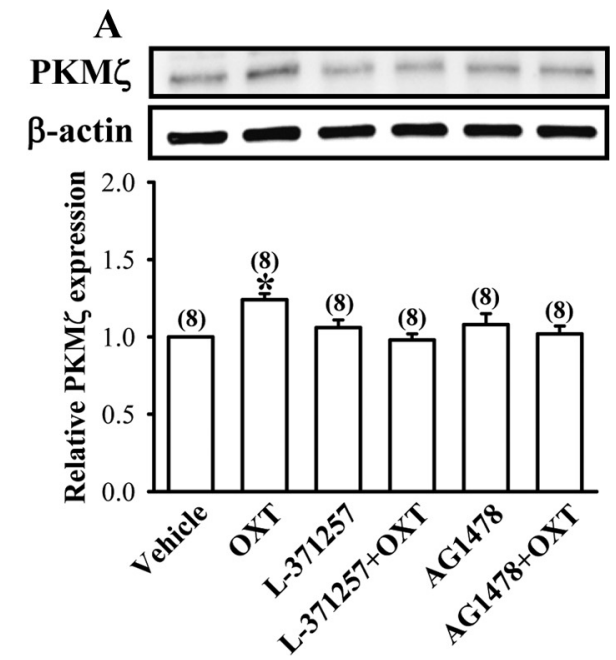

B
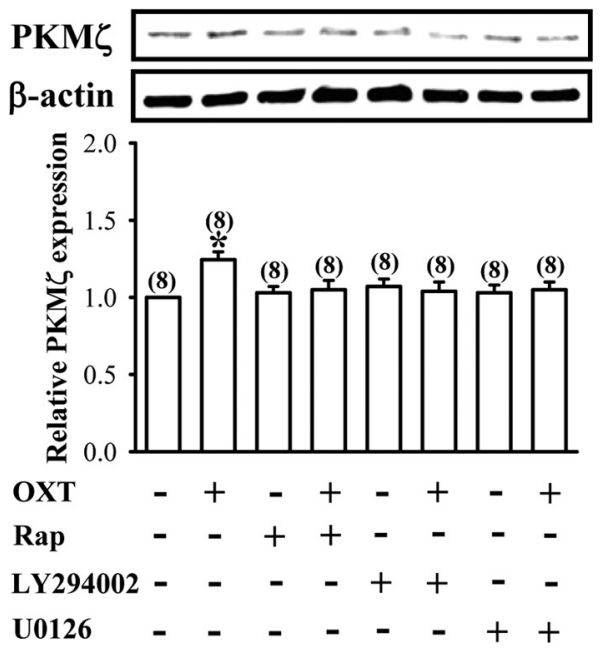

Figure 9. OXT stimulates PKM $\xi$ synthesis in cultured hippocampal neurons. $A$, Representative immunoblot and summary histogram showing pretreatment of the cultured hippocampal

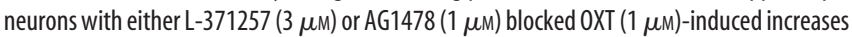
in PKM $\xi$ expression. $\boldsymbol{B}$, Representative immunoblot and summary histogram showing 0XT (1 $\mu \mathrm{M})$-induced increases in PKM $\xi$ expression was blocked by pretreatment of the cultured hippocampal neurons with rapamycin (Rap, $200 \mathrm{~nm})$, LY294002 $(20 \mu \mathrm{M})$, or U0126 (10 $\mu \mathrm{M})$, respectively. Inhibitors were applied $30 \mathrm{~min}$ before the addition of OXT for $30 \mathrm{~min}$. The total number of experiments is indicated by $n$ in parenthesis. Data are represented as mean \pm SEM. ${ }^{*} p<0.05$ compared with vehicle-treated group.

\section{Discussion}

The present study demonstrates that OXT enhances the maintenance of LTP in hippocampal CA1 region of both sexes via activation of the OXTR-associated conventional PLC signaling pathway. This enhancement requires a rapid and persistent increase in dendritic PKM $\zeta$ protein synthesis via an mTORmediated mechanism. More importantly, OXT-induced increases in $\mathrm{PKM} \zeta$ expression relies on the transactivation of EGFR and subsequent activation of its downstream PI3K and ERK1/2 signaling pathways. Furthermore, our results reveal a functional contribution of endogenous OXT in the maintenance of late-phase LTP induced by multiple trains of TS.

OXT has previously been shown to affect either the establishment or the maintenance of LTP at excitatory central synapses (Dubrovsky et al., 2002; Tomizawa et al., 2003; Fang et al., 2008), but the exact underlying mechanisms still remain 

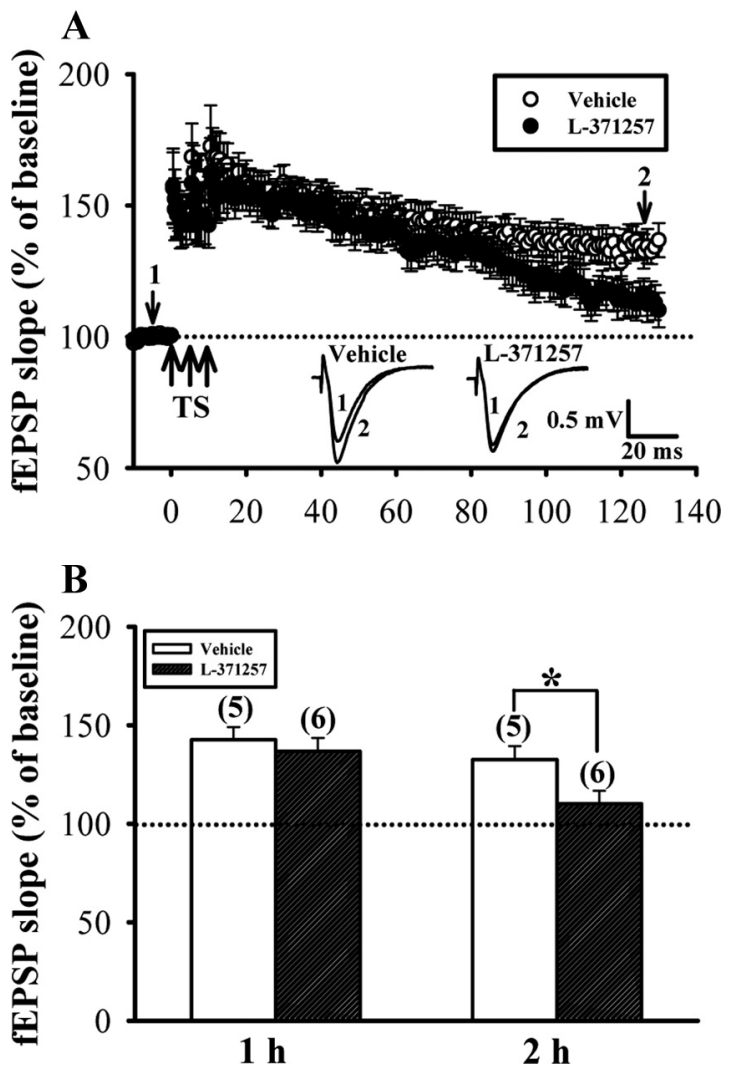

Figure 10. Blockade of OXTR significantly inhibits the maintenance of late-phase LTP. $\boldsymbol{A}$, Summary of experiments showing pretreatment of hippocampal slices with OXTR antagonist L-371257 (3 $\mu \mathrm{m}$ ) significantly inhibited late-phase LTP induced by three trains of TS at $100 \mathrm{~Hz}$ separated by an intertrain interval of $5 \mathrm{~min}$. $\boldsymbol{B}$, Summary histogram depicting the effect of L-371257 on late-phase LTP in slices from female dorsal hippocampus. The magnitudes of LTP were measured $1 \mathrm{~h}(50-60 \mathrm{~min})$ or $2 \mathrm{~h}(110-120 \mathrm{~min})$ after TS. Representative traces of fEPSPs were taken at the time indicated by number. Dash lines show level of baseline. The total number of animals examined is indicated by $n$ in parenthesis. Data are represented as mean \pm SEM. ${ }^{*} p<0.05$ compared with vehicle-treated group.

obscure. Dubrovsky et al. (2002) have shown that intracerebroventricular injection of OXT can elicit synaptic depression of previously established LTP in the dentate gyrus of anesthetized rats via its inhibitory effect on ATPase and ectoprotein kinase activity. On the contrary, Tomizawa et al. (2003) showed that OXT enhances hippocampal CA1 LTP in vitro and cognitive function in vivo during motherhood in mice through the activation of MAPK cascade and consequent cAMP-responsive element binding protein phosphorylation. In accordance with findings by Tomizawa et al. (2003), the current results show that activation of OXTR enhances the ability of subthreshold synaptic stimulation to induce late-phase LTP. We have, in addition, extended these findings by demonstrating that OXT exerts its LTP-enhancing effect via the activation of conventional OXTRassociated PLC and the signaling pathways downstream of EGFR.

An important finding in this study is the identification of $\mathrm{PKM} \zeta$ that contributes to OXT-induced enhancement of LTP. $\mathrm{PKM} \zeta$ is expressed at relatively high levels in the hippocampus (Naik et al., 2000) and de novo protein synthesis of PKM $\zeta$ has been widely implicated in the maintenance of late-phase LTP (Sacktor et al., 1993; Ling et al., 2002; Pastalkova et al., 2006). The observation that inhibiting PKM $\zeta$ with ZIP effectively reversed established LTP induced by conjoint activation of OXTR and subthreshold stimulation supports a pivotal role for $\mathrm{PKM} \zeta$ in the maintenance of OXT-induced LTP (Fig. 4). Furthermore, we propose that OXTR activation regulates the increased translation of PKM $\zeta$ from preexisting mRNAs, rather than increased transcription, because incubation of slices with the transcription inhibitor actinomycin D does not affect OXT-induced increases in PKM $\zeta$ expression (Fig. 5C) and PKM $\zeta$ protein increases within minutes after OXT treatment, too rapid for new transcription of PKM $\zeta$ mRNAs (Kelleher et al., 2004). More importantly, our data indicate that OXT stimulated PKM $\zeta$ protein synthesis in isolated synaptoneurosomes, raising the possibility that the new $\mathrm{PKM} \zeta$ protein synthesis occurs locally in the synaptodendritic compartment. These findings confirm previous reports showing that PKM $\zeta$ mRNAs are locally available at synapses for sitespecific translation (Muslimov et al., 2004; Kelly et al., 2007). Due to the specificity of OXT-induced synthesis of $\mathrm{PKM} \zeta$ to enhance the synaptic responses of the tetanized pathway without affecting baseline synaptic transmission, our results raise the possibility that newly generated $\mathrm{PKM} \zeta$ may act as a plasticity-related protein (PRP) to interact with recently potentiated "tagged" synapses and then prolong potentiation. In support of this, Sajikumar et al. (2005) indicated that PKM $\zeta$ is an LTP-specific PRP and is crucial for the transformation of early- into late-LTP during both synaptic tagging and cross-tagging. Furthermore, our observation that OXT-induced increases in PKM $\zeta$ protein synthesis were blocked by PI3K, MEK, and mTOR inhibitors supports a mechanism involving the PI3K/Akt/mTOR and ERK1/2 signaling pathways. This is in line with earlier reports indicating that multiple signaling kinases important for LTP induction, in particular the $\mathrm{Ca}^{2+}$ /calmodulin-dependent protein kinase II, MAPK, PI3K, and $\mathrm{mTOR}$, can release the translational block on PKM $\zeta$ synthesis in dendrites (Kelly et al., 2007; Sacktor, 2011).

A pressing question that follows these observations is how OXT activates PI3K and ERK1/2 signaling pathways. Our finding that the OXT-induced increases in PI3K and ERK1/2 activation were blocked by OXTR, PLC, and EGFR inhibitors supports pathways involving OXTR-associated conventional PLC and EGFR transactivation. This study provides, to our knowledge, the first evidence for the transactivation of EGFR by OXTR in brain. This regulation has been demonstrated in myometrial and epithelial cells (Zhong et al., 2003; Krishnaswamy et al., 2010), where the EGFR tyrosine kinase may serve as an important effector in a signaling pathway connecting OXTR to PI3K and ERK1/2 to regulate gene expression. Interestingly, it was noted that the inhibition of PLC with U73122 completely prevented OXT-induced increases in PI3K and ERK1/2 activation, suggesting that OXTinduced PLC activation mediates the transactivation of EGFR and its downstream PI3K and ERK1/2 signaling. Although several previous studies have indicated that extracellular release EGFR ligands and MMP activity are required for GPCR-induced EGFR transactivation (Prenzel et al., 1999; Chiu et al., 2005), our results do not support a role for EGFR ligands or MMP activity in mediating the crosstalk between OXTR and EGFR in hippocampal neurons (Fig. 8). This discrepancy in findings can be partially reconciled by accounting for differences in GPCR types and cell types, resulting in activation of different cellular processes that vary in their mode of action. Although the mechanism by which OXTR/PLC transactivates EGFR remains to be established, activation of proline-rich tyrosine kinase 2 ( $\mathrm{Pyk} 2)$ and its association with Src kinase may be involved in this event. Indeed, it has been reported that OXT can stimulate angiogenesis via a PLCdependent activation of Pyk2 and Src mechanism (Cattaneo et al., 2009) and that Pyk2 is involved in $\mathrm{Ca}^{2+}$-stimulated EGFR transactivation in PC12 cells (Zwick et al., 1999). 
How does PKM $\zeta$ maintain OXT-induced LTP? Although we did not address this issue in the present study, several candidate mechanisms have been recently proposed. Yao et al. (2008) demonstrated that PKM $\zeta$ maintains late-phase LTP by persistently upregulating $\mathrm{N}$-ethylmaleimide-sensitive factor/glutamate receptor subunit 2-dependent AMPA receptor trafficking pathway to increase postsynaptic AMPA receptors. Interestingly, it has been suggested that immediately after translation, PKM $\zeta$ exhibits a low level of activity until it binds to phosphoinositide-dependent protein kinase 1 (PDK1), which phosphorylates PKM $\zeta$ at Thr410 and converts it into a conformation with high constitutive activity (Kelly et al., 2007). As such, it is plausible that the phosphorylation of PKM $\zeta$ by PDK1 may ensure optimal PKM $\zeta$ activity to maintain OXT-induced LTP. However, we were unable to assess levels of phosphorylated PKM $\zeta$ in the synaptoneurosomes, since available phosphorylation site-specific antibodies did not yield a reliable signal. Further investigation is needed to examine this possibility.

What could be the functional consequence of OXT-induced enhancement of LTP? Given LTP, in hippocampal CA1 region, is generally assumed as a synaptic mechanism underlying the formation of spatial and episodic memories (Bliss and Collingridge, 1993; Martin et al., 2000), this enhancement of LTP by OXT may therefore promote long-term memory formation. While we did not directly test the effects of OXT on behavioral performance in hippocampus-dependent tasks in this study, a prior study has shown that intracerebroventricular injection of OXT into virgin female mice significantly improved long-term spatial memory in the radial arm maze, whereas an injection of OXTR antagonist in multiparous mice inhibited the improved spatial memory (Tomizawa et al., 2003). It is worth noting, however, that de Oliveira et al. (2007) showed that systemically administered OXT before testing impaired memory retrieval for the step-down inhibitory avoidance, a hippocampus-dependent associative learning task (Gold, 1986). Such amnesic effect of OXT on long-term memory might be caused by a decrease in glucocorticoid release from the adrenal gland, which is critically involved in enhancing memory of inhibitory avoidance training (Borrell et al., 1983). These results let us speculate that the effects of OXT on long-term memory formation could be polymodal, depending on the dose, route of administration, and types of memory tasks. Furthermore, the present study extend previous work (Tomizawa et al., 2003) by showing that OXT enhances the maintenance of LTP in the CA1 region of hippocampal slices from both nulliparous female and male rats, contradicting the idea that OXT exerts its effects in a sex-dependent manner (Ferguson et al., 2000; Monks et al., 2003).

Although our data show that OXT $(1 \mu \mathrm{M})$ can consistently enhance the maintenance of LTP, it is unclear whether the endogenous OXT level could trigger this enhancing action. Because OXTR antagonist effectively prevented the maintenance of latephase LTP induced by three trains of TS, we suggest that OXT release in response to strong conditioning stimuli is important for late-phase LTP maintenance.

In conclusion, we provide compelling evidence that OXTR activation facilitates induction of a protein-synthesis-dependent form of late-phase LTP in hippocampal CA1 region. Our data support a sequential signaling model, in which OXTR activation stimulates PLC, leading to the transactivation of EGFR, which in turn activates PI3K and ERK1/2 to increase dendritic PKM $\zeta$ protein synthesis via mTOR signaling, thereby contributing to the maintenance of LTP.

\section{References}

Balkowiec A, Katz DM (2002) Cellular mechanisms regulating activitydependent release of native brain-derived neurotrophic factor from hippocampal neurons. J Neurosci 22:10399-10407. Medline

Bliss TV, Collingridge GL (1993) A synaptic model of memory: long-term potentiation in the hippocampus. Nature 361:31-39. CrossRef Medline

Borrell J, De Kloet ER, Versteeg DH, Bohus B (1983) Inhibitory avoidance deficit following short-term adrenalectomy in the rat: the role of adrenal catecholamines. Behav Neural Biol 39:241-258. CrossRef Medline

Brown EJ, Schreiber SL (1996) A signaling pathway to translational control. Cell 86:517-520. CrossRef Medline

Buijs RM, Swaab DF (1979) Immuno-electron microscopical demonstration of vasopressin and oxytocin synapses in the limbic system of the rat. Cell Tissue Res 204:355-365. Medline

Cattaneo MG, Lucci G, Vicentini LM (2009) Oxytocin stimulates in vitro angiogenesis via a Pyk-2/Src-dependent mechanism. Exp Cell Res 315: 3210-3219. CrossRef Medline

Chandler LJ, Sutton G, Dorairaj NR, Norwood D (2001) N-methyl-Daspartate receptor-mediated bidirectional control of extracellular signalregulated kinase activity in cortical neuronal cultures. J Biol Chem 276: 2627-2636. CrossRef Medline

Chiu T, Santiskulvong C, Rozengurt E (2005) EGF receptor transactivation mediates ANG II-stimulated mitogenesis in intestinal epithelial cells through the PI3-kinase/Akt/mTOR/p70S6K1 signaling pathway. Am J Physiol Gastrointest Liver Physiol 288:G182-G194. CrossRef Medline

Cohen H, Kaplan Z, Kozlovsky N, Gidron Y, Matar MA, Zohar J (2010) Hippocampal microinfusion of oxytocin attenuates the behavioural response to stress by means of dynamic interplay with the glucocorticoidcatecholamine responses. J Neuroendocrinol 22:889-904. Medline

Deadwyler SA, Dunwiddie T, Lynch G (1987) A critical level of protein synthesis is required for long-term potentiation. Synapse 1:90-95. CrossRef Medline

de Oliveira LF, Camboim C, Diehl F, Consiglio AR, Quillfeldt JA (2007) Glucocorticoid-mediated effects of systemic oxytocin upon memory retrieval. Neurobiol Learn Mem 87:67-71. CrossRef Medline

Dubrovsky B, Harris J, Gijsbers K, Tatarinov A (2002) Oxytocin induces long-term depression on the rat dentate gyrus: possible ATPase and ectoprotein kinase mediation. Brain Res Bull 58:141-147. CrossRef Medline

Fang LY, Quan RD, Kaba H (2008) OxytocDubrovskyin facilitates the induction of long-term potentiation in the accessory olfactory bulb. Neurosci Lett 438:133-137. CrossRef Medline

Ferguson JN, Young LJ, Hearn EF, Matzuk MM, Insel TR, Winslow JT (2000) Social amnesia in mice lacking the oxytocin gene. Nat Genet 25: 284-288. CrossRef Medline

Franke TF, Yang SI, Chan TO, Datta K, Kazlauskas A, Morrison DK, Kaplan DR, Tsichlis PN (1995) The protein kinase encoded by the Akt protooncogene is a target of the PDGF-activated phosphatidylinositol 3-kinase. Cell 81:727-736. CrossRef Medline

Frey U, Krug M, Reymann KG, Matthies H (1988) Anisomycin, an inhibitor of protein synthesis, blocks late phases of LTP phenomena in the hippocampal CA1 region in vitro. Brain Res 452:57-65. CrossRef Medline

Gainer H, Wray S (1992) Oxytocin and vasopressin. From genes to peptides. Ann N Y Acad Sci 652:14-28. CrossRef Medline

Gimpl G, Fahrenholz F (2001) The oxytocin receptor system: structure, function, and regulation. Physiol Rev 81:629-683. Medline

Gold PE (1986) The use of avoidance training in studies of modulation of memory storage. Behav Neural Biol 46:87-98. CrossRef Medline

Hardt O, Migues PV, Hastings M, Wong J, Nader K (2010) PKM $\zeta$ maintains 1-day- and 6-day-old long-term object location but not object identity memory in dorsal hippocampus. Hippocampus 20:691-695. Medline

Hollingsworth EB, McNeal ET, Burton JL, Williams RJ, Daly JW, Creveling CR (1985) Biochemical characterization of a filtered synaptoneurosome preparation from guinea pig cerebral cortex: cyclic adenosine $3^{\prime}: 5^{\prime}$ monophosphate-generating systems, receptors, and enzymes. J Neurosci 5:2240-2253. Medline

Huang CC, Hsu KS (2006) Sustained activation of metabotropic glutamate receptor 5 and protein tyrosine phosphatases mediate the expression of (S)-3,5-dihydroxyphenylglycine-induced long-term depression in the hippocampal CA1 region. J Neurochem 96:179-194. CrossRef Medline

Huang YF, Yang CH, Huang CC, Tai MH, Hsu KS (2010) Pharmacological and genetic accumulation of hypoxia-inducible factor- $1 \alpha$ enhances excitatory synaptic transmission in hippocampal neurons through the produc- 
tion of vascular endothelial growth factor. J Neurosci 30:6080-6093. CrossRef Medline

Huttner WB, Schiebler W, Greengard P, De Camilli P (1983) Synapsin I (protein I), a nerve terminal-specific phosphoprotein. III. Its association with synaptic vesicles studied in a highly purified synaptic vesicle preparation. J Cell Biol 96:1374-1388. CrossRef Medline

Insel TR, Gelhard R, Shapiro LE (1991) The comparative distribution of forebrain receptors for neurohypophyseal peptides in monogamous and polygamous mice. Neuroscience 43:623-630. CrossRef Medline

Kalmes A, Vesti BR, Daum G, Abraham JA, Clowes AW (2000) Heparin blockade of thrombin-induced smooth muscle cell migration involves inhibition of epidermal growth factor (EGF) receptor transactivation by heparin-binding EGF-like growth factor. Circ Res 87:92-98. CrossRef Medline

Kelleher RJ 3rd, Govindarajan A, Tonegawa S (2004) Translational regulatory mechanisms in persistent forms of synaptic plasticity. Neuron 44:59-73. CrossRef Medline

Kelly MT, Crary JF, Sacktor TC (2007) Regulation of protein kinase M synthesis by multiple kinases in long-term potentiation. J Neurosci 27: 3439-3444. CrossRef Medline

Krishnaswamy N, Lacroix-Pepin N, Chapdelaine P, Taniguchi H, Kauffenstein G, Chakravarti A, Danyod G, Fortier MA (2010) Epidermal growth factor receptor is an obligatory intermediate for oxytocin-induced cyclooxygenase 2 expression and prostaglandin $\mathrm{F} 2$ alpha production in bovine endometrial epithelial cells. Endocrinology 151:1367-1374. CrossRef Medline

Laudanna C, Mochly-Rosen D, Liron T, Constantin G, Butcher EC (1998) Evidence of $\zeta$ protein kinase $\mathrm{C}$ involvement in polymorphonuclear neutrophil integrin-dependent adhesion and chemotaxis. J Biol Chem 273: 30306-30315. CrossRef Medline

Lee HJ, Macbeth AH, Pagani JH, Young WS 3rd (2009) Oxytocin: the great facilitator of life. Prog Neurobiol 88:127-151. Medline

Leuner B, Caponiti JM, Gould E (2012) Oxytocin stimulates adult neurogenesis even under conditions of stress and elevated glucocorticoids. Hippocampus 22:861-868. CrossRef Medline

Levitzki A, Gazit A (1995) Tyrosine kinase inhibition: an approach to drug development. Science 267:1782-1788. CrossRef Medline

Lin HJ, Huang CC, Hsu KS (2006) Effects of neonatal dexamethasone treatment on hippocampal synaptic function. Ann Neurol 59:939-951. CrossRef Medline

Ling DS, Benardo LS, Serrano PA, Blace N, Kelly MT, Crary JF, Sacktor TC (2002) Protein kinase $\mathrm{M} \zeta$ is necessary and sufficient for LTP maintenance. Nat Neurosci 5:295-296. CrossRef Medline

Martin SJ, Grimwood PD, Morris RG (2000) Synaptic plasticity and memory: an evaluation of the hypothesis. Annu Rev Neurosci 23:649-711. CrossRef Medline

Meyer-Lindenberg A, Domes G, Kirsch P, Heinrichs M (2011) Oxytocin and vasopressin in the human brain: social neuropeptides for translational medicine. Nat Rev Neurosci 12:524-538. CrossRef Medline

Monks DA, Lonstein JS, Breedlove SM (2003) Got milk? Oxytocin triggers hippocampal plasticity. Nat Neurosci 6:327-328. CrossRef Medline

Muslimov IA, Nimmrich V, Hernandez AI, Tcherepanov A, Sacktor TC, Tiedge H (2004) Dendritic transport and localization of protein kinase

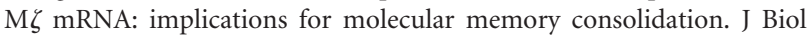
Chem 279:52613-52622. CrossRef Medline

Naik MU, Benedikz E, Hernandez I, Libien J, Hrabe J, Valsamis M, DowEdwards D, Osman M, Sacktor TC (2000) Distribution of protein kinase $\mathrm{M} \zeta$ and the complete protein kinase $\mathrm{C}$ isoform family in rat brain. J Comp Neurol 426:243-258. CrossRef Medline

Neumann ID (2008) Brain oxytocin: a key regulator of emotional and social behaviors in both females and males. J Neuroendocrinol 20:858-865. CrossRef Medline

Neumann ID, Landgraf R (2008) Advances in vasopressin and oxytocinfrom genes to behavior to disease. Prog Brain Res 170:xi-xiii. CrossRef Medline

Nguyen PV, Abel T, Kandel ER (1994) Requirement of a critical period of transcription for induction of a late phase of LTP. Science 265:1104-1107. CrossRef Medline

Pastalkova E, Serrano P, Pinkhasova D, Wallace E, Fenton AA, Sacktor TC (2006) Storage of spatial information by the maintenance mechanism of LTP. Science 313:1141-1144. CrossRef Medline

Pedersen CA, Prange AJ Jr (1979) Induction of maternal behavior in virgin rats after intracerebroventricular administration of oxytocin. Proc Natl Acad Sci U S A 76:6661-6665. CrossRef Medline

Perkinton MS, Ip JK, Wood GL, Crossthwaite AJ, Williams RJ (2002) Phosphatidylinositol 3-kinase is a central mediator of NMDA receptor signalling to MAP kinase (Erk1/2), Akt/PKB and CREB in striatal neurones. J Neurochem 80:239-254. CrossRef Medline

Prenzel N, Zwick E, Daub H, Leserer M, Abraham R, Wallasch C, Ullrich A (1999) EGF receptor transactivation by G-protein-coupled receptors requires metalloproteinase cleavage of proHB-EGF. Nature 402:884-888. Medline

Raab G, Klagsbrun M (1997) Heparin-binding EGF-like growth factor. Biochim Biophys Acta 1333:F179-F199. Medline

Rao A, Steward O (1991) Evidence that protein constituents of postsynaptic membrane specializations are locally synthesized: analysis of proteins synthesized within synaptosomes. J Neurosci 11:2881-2895. Medline

Sacktor TC (2011) How does PKM $\zeta$ maintain long-term memory? Nat Rev Neurosci 12:9-15. CrossRef Medline

Sacktor TC, Osten P, Valsamis H, Jiang X, Naik MU, Sublette E (1993) Persistent activation of the $\zeta$ isoform of protein kinase $\mathrm{C}$ in the maintenance of long-term potentiation. Proc Natl Acad Sci U S A 90:8342-8346. CrossRef Medline

Sajikumar S, Navakkode S, Sacktor TC, Frey JU (2005) Synaptic tagging and cross-tagging: the role of protein kinase $\mathrm{M} \zeta$ in maintaining long-term potentiation but not long-term depression. J Neurosci 25:5750-5756. CrossRef Medline

Serrano P, Yao Y, Sacktor TC (2005) Persistent phosphorylation by protein kinase $\mathrm{M} \zeta$ maintains late-phase long-term potentiation. J Neurosci 25: 1979-1984. CrossRef Medline

Serrano P, Friedman EL, Kenney J, Taubenfeld SM, Zimmerman JM, Hanna J, Alberini C, Kelley AE, Maren S, Rudy JW, Yin JC, Sacktor TC, Fenton AA (2008) PKM $\zeta$ maintains spatial, instrumental, and classically conditioned long-term memories. PLoS Biol 6:2698-2706. Medline

Sofroniew MV (1983) Morphology of vasopressin and oxytocin neurons and their central and vascular projections. Prog Brain Res 60:101-114. CrossRef Medline

Stanton PK, Sarvey JM (1984) Blockade of long-term potentiation in rat hippocampal CA1 region by inhibitors of protein synthesis. J Neurosci 4:3080-3088. Medline

Stoica L, Zhu PJ, Huang W, Zhou H, Kozma SC, Costa-Mattioli M (2011) Selective pharmacogenetic inhibition of mammalian target of Rapamycin complex I (mTORC1) blocks long-term synaptic plasticity and memory storage. Proc Natl Acad Sci U S A 108:3791-3796. CrossRef Medline

Tang SJ, Reis G, Kang H, Gingras AC, Sonenberg N, Schuman EM (2002) A rapamycin-sensitive signaling pathway contributes to long-term synaptic plasticity in the hippocampus. Proc Natl Acad Sci U S A 99:467-472. CrossRef Medline

Tapley P, Lamballe F, Barbacid M (1992) K252a is a selective inhibitor of the tyrosine protein kinase activity of the trk family of oncogenes and neurotrophin receptors. Oncogene 7:371-381. Medline

Tomizawa K, Iga N, Lu YF, Moriwaki A, Matsushita M, Li ST, Miyamoto O, Itano T, Matsui H (2003) Oxytocin improves long-lasting spatial memory during motherhood through MAP kinase cascade. Nat Neurosci 6:384-390. CrossRef Medline

Tsokas P, Grace EA, Chan P, Ma T, Sealfon SC, Iyengar R, Landau EM, Blitzer $\mathrm{RD}$ (2005) Local protein synthesis mediates a rapid increase in dendritic elongation factor $1 \mathrm{~A}$ after induction of late long-term potentiation. J Neurosci 25:5833-5843. CrossRef Medline

Tyzio R, Cossart R, Khalilov I, Minlebaev M, Hübner CA, Represa A, Ben-Ari Y, Khazipov R (2006) Maternal oxytocin triggers a transient inhibitory switch in GABA signaling in the fetal brain during delivery. Science 314: 1788-1792. CrossRef Medline

Veinante P, Freund-Mercier MJ (1997) Distribution of oxytocin- and vasopressin-binding sites in the rat extended amygdala: a histoautoradiographic study. J Comp Neurol 383:305-325. Medline

Wigström H, Gustafsson B (1983) Facilitated induction of hippocampal longlasting potentiation during blockade of inhibition. Nature 301:603-604. CrossRef Medline

Yang PC, Yang CH, Huang CC, Hsu KS (2008) Phosphatidylinositol 3-kinase activation is required for stress protocol-induced modification of hippocampal synaptic plasticity. J Biol Chem 283:2631-2643. Medline

Yao Y, Kelly MT, Sajikumar S, Serrano P, Tian D, Bergold PJ, Frey JU, Sacktor TC (2008) $\mathrm{PKM} \zeta$ maintains late long-term potentiation by $N$-ethylmaleimide- 
sensitive factor/GluR2-dependent trafficking of postsynaptic AMPA receptors. J Neurosci 28:7820-7827. CrossRef Medline

Young WS 3rd, Gainer H (2003) Transgenesis and the study of expression, cellular targeting and function of oxytocin, vasopressin and their receptors. Neuroendocrinology 78:185-203. CrossRef Medline

Zaninetti M, Raggenbass M (2000) Oxytocin receptor agonists enhance inhibitory synaptic transmission in the rat hippocampus by activating interneurons in stratum pyramidale. Eur J Neurosci 12:3975-3984. CrossRef Medline
Zhong M, Yang M, Sanborn BM (2003) Extracellular signal-regulated kinase $1 / 2$ activation by myometrial oxytocin receptor involves $G_{\alpha q} G_{\beta \gamma}$ and epidermal growth factor receptor tyrosine kinase activation. Endocrinology 144:2947-2956. CrossRef Medline

Zwick E, Wallasch C, Daub H, Ullrich A (1999) Distinct calcium-dependent pathways of epidermal growth factor receptor transactivation and Pyk2 tyrosine phosphorylation in PC12 cells. J Biol Chem 274:20989-20996. CrossRef Medline 